NBER WORKING PAPER SERIES

\title{
LABOR MARKET, FINANCIAL CRISES AND INFLATION: JOBLESS AND WAGELESS RECOVERIES
}

\author{
Guillermo A. Calvo \\ Fabrizio Coricelli \\ Pablo Ottonello \\ Working Paper 18480 \\ http://www.nber.org/papers/w18480
NATIONAL BUREAU OF ECONOMIC RESEARCH
1050 Massachusetts Avenue
Cambridge, MA 02138
October 2012

Previously circulated as "The Labor Market Consequences of Financial Crises With or Without Inflation: Jobless and Wageless Recoveries." We are grateful for very valuable comments to Stijn Claessens, Victor Elias, Gaston Gelos, Ernesto Talvi, the participants of XVI Conference of the Central Bank of Chile, IMF Jobs and Growth Seminar, LACEA-LAMES 2012 Annual Meetings held in Lima, Peru, and the 2013 CEPR European Summer Symposium in International Macroeconomics (ESSIM), held in Izmir, Turkey. We also thank Ambrogio Cesa-Bianchi, Luis Felipe Cespedes and Alessandro Rebucci for sharing their dataset on house prices. The views expressed herein are those of the authors and do not necessarily reflect the views of the National Bureau of Economic Research.

NBER working papers are circulated for discussion and comment purposes. They have not been peerreviewed or been subject to the review by the NBER Board of Directors that accompanies official NBER publications.

(C) 2012 by Guillermo A. Calvo, Fabrizio Coricelli, and Pablo Ottonello. All rights reserved. Short sections of text, not to exceed two paragraphs, may be quoted without explicit permission provided that full credit, including (C) notice, is given to the source. 
Labor Market, Financial Crises and Inflation: Jobless and Wageless Recoveries

Guillermo A. Calvo, Fabrizio Coricelli, and Pablo Ottonello

NBER Working Paper No. 18480

October 2012, Revised June 2014

JEL No. E2,E31,E44,F3,F32

\section{ABSTRACT}

This paper uses a sample of 116 recession episodes in developed and emerging market economies to compare the labor-market recovery during financial crises with that of other recession episodes. It documents two new stylized facts. First, labor-market recovery from financial crises is characterized by either higher unemployment ("jobless recovery") or a lower real wage ("wageless recovery"). Second, inflation determines the type of recovery: low inflation (below 30 percent annual rate) is associated with jobless recovery, while high inflation is associated with wageless recovery. The paper shows that this pattern of labor recovery from financial crises is consistent with a simple model in which collateral requirements are higher (lower) when a larger share of labor costs (physical capital expenditure) is involved in a loan contract.

Guillermo A. Calvo

Columbia University

School of International and Public Affairs

420 West 118th St, Room 1303B

MC3332

New York, NY 10027

and NBER

gc2286@columbia.edu

Fabrizio Coricelli

Paris School of Economics

Universite' Paris 1

fabrizio.coricelli@univ-paris1.fr
Pablo Ottonello

Department of Economics

$420 \mathrm{~W} 118$ th Street

New York, NY 10027

po2171@columbia.edu 
The slow recovery of unemployment has been one of the most salient features in the policy debate that accompanied the Great Recession. The fact that, in the context of high unemployment, US output has recovered its precrisis level has lead many analysts, in both academic and policy circles, to label the pattern a "jobless recovery" (see Figure 1). In Europe, the pattern of unemployment recovery seems to be even more dramatic: Six years after the recession began, unemployment has not yet begun to recover its precrisis level.

This paper casts light on the reasons for jobless recovery in the Great Recession by studying labor-market recovery in a sample of 116 postwar recession episodes-prior to the Great Recession-in developed (DMs) and emerging market economies (EMs). We document two new stylized facts. First, in "low-inflation" recession episodes (i.e., annual inflation below 30 percent), financial crises tend to be followed by greater unemployment than in other recession episodes. Second, in "high-inflation" recession episodes, financial crises are not followed by jobless recoveries but by "wageless recoveries," characterized by a lower real wage once output recovers its trend. These findings are summarized in Figure 2, which compares the behavior of DMs' and EMs' respective labor markets during financial crises, relative to other episodes.

\section{a) United States}

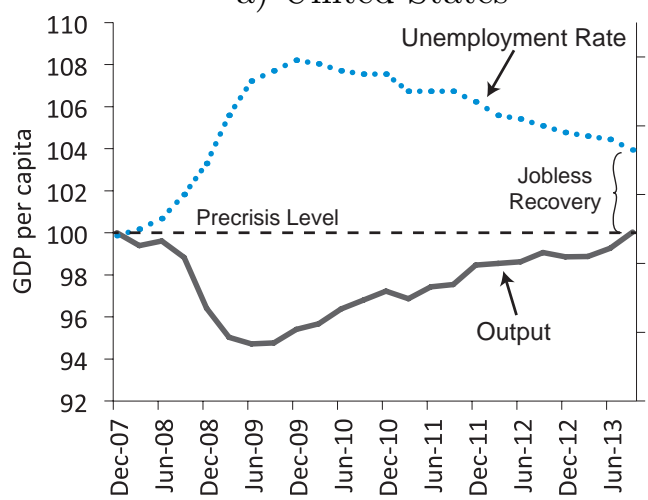

b) Euro Area

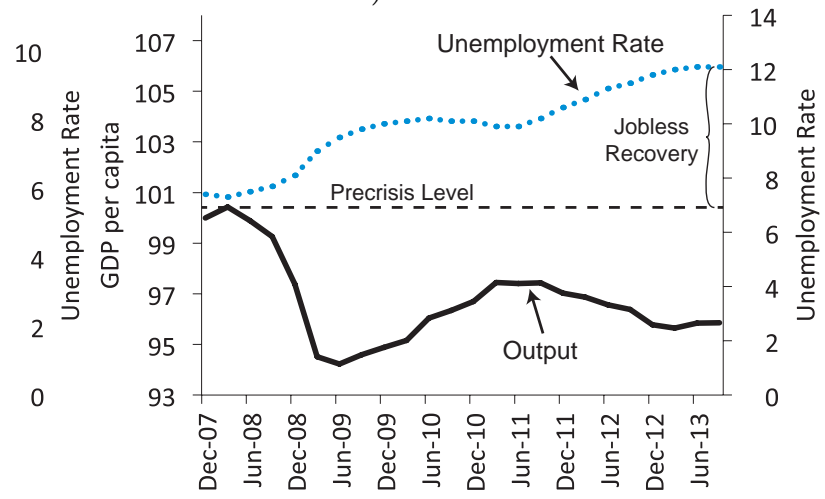

Figure 1: Jobless recovery during the Great Recession

Notes: Euro Area includes EA-17, Eurostat definition; GDP in real terms, peak = 100; unemployment rate in percent. Seasonally adjusted figures.

In DMs, where inflation in the postwar era has been relatively low, financial crises have been followed by recoveries in which joblessness was significantly higher than in other recessions. This is in line with Reinhart and Reinhart (2010): During the ten years following financial crises, unemployment rates remain on average five percentage points above the average rate ten years prior to the crisis. Similar evidence is provided by Knotek and Terry (2009), who show that, for the "big five" banking crises (Spain 1977, Norway 1987, Finland 1991, Sweden 1991, Japan 1992), unemployment rates have been higher 

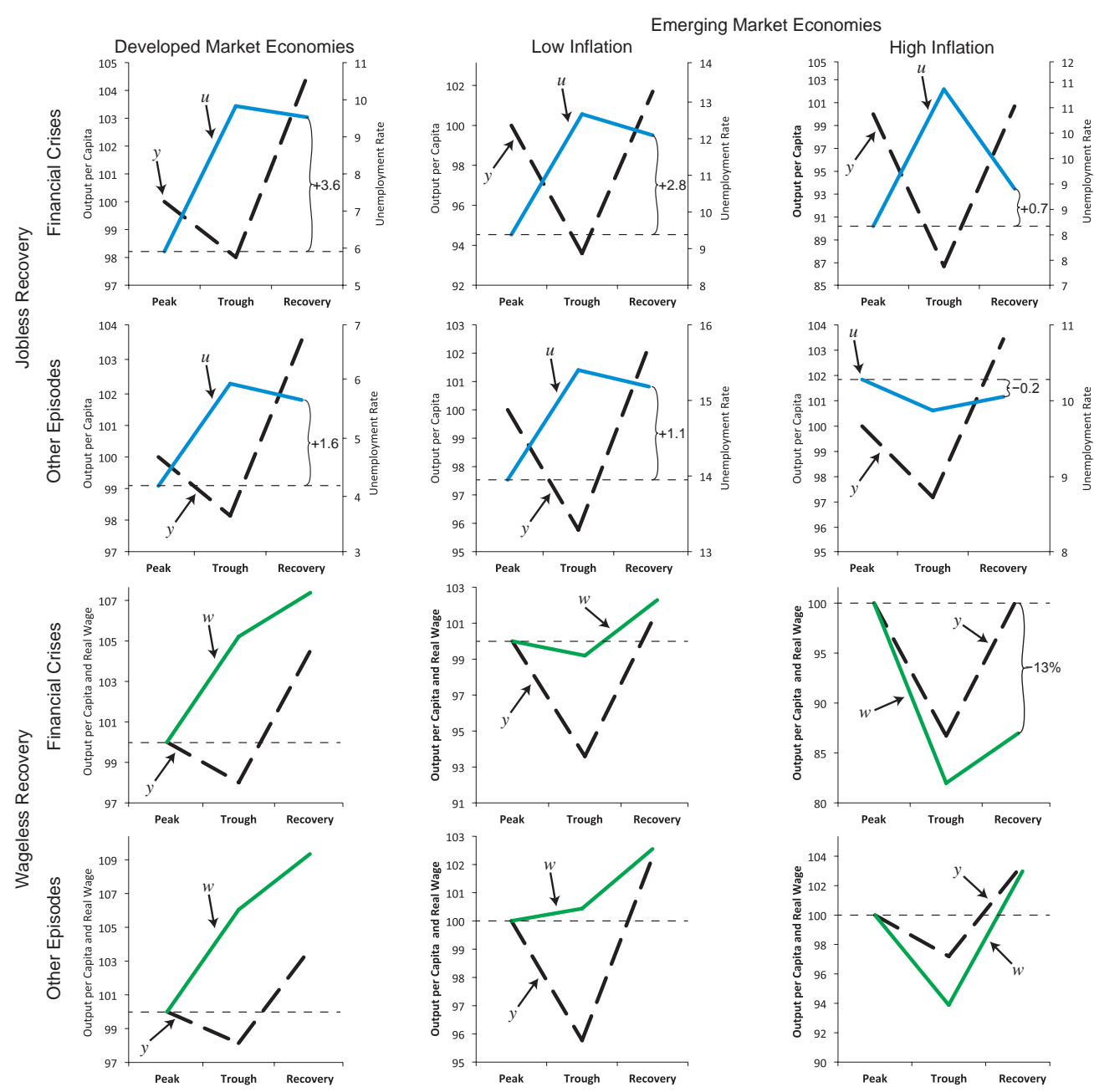

Figure 2: Labor Market Recovery, Financial Crises and Inflation

Notes: See Section 1 for a description of the sample and data; $u$ refers to the unemployment rate, in percent; $y$ refers to real GDP per capita, and $w$ refers to real wages, peak $=100$.

and more persistent than in recessions not associated with banking crises.

In EMs, there is a much higher dispersion in inflation rates during financial crises. Exploiting these differences in inflation rates, we find again a sluggish adjustment of labor markets during the recovery from financial crises, but the nature of such adjustment varies with inflation. High-inflation recession episodes are not associated with jobless recoveries but with wageless recoveries. In contrast, low-inflation EMs display a pattern similar to that observed in DMs, with financial crises associated with more intense jobless recoveries. The findings are in line with models of nominal wage rigidities, where a price spike would lower the rate of unemployment (for a recent study in this direction showing the importance of wage rigidity in a crisis environment, see Schmitt-Grohé and Uribe, 2013).

The paper conducts an econometric analysis finding that the association between financial crises and jobless and wageless recoveries, as shown in Figure 2, is robust to 
controlling for countries' characteristics (such as labor-market indicators, secular growth, financial development, and country size) and to characteristics of the recession episodes (such as duration of the episode or the depth of the output contraction). To provide evidence on the effect of financial crises in this association, we also carry out an instrumental variable (IV) strategy using credit-market outcomes prior to the recession episode in order to identify the exogenous effect of financial crises on jobless recoveries.

A common explanation given for the high unemployment observed in the Great Recession is that output has not recovered its trend. In this line, several papers have recently argued that jobless recoveries are not a pattern observed in the data, based on the stability of Okun's law (e.g., Ball, Leigh and Loungani, 2013; Galí, Smets and Wouters, 2012). We show that a key difference between our findings and the results obtained in this literature is related to the measure of jobless recovery used. Estimations of Okun's law typically focus on the cyclical component of unemployment. In our study, we measure jobless recovery as the change in unemployment rate from output peak to recovery. In fact, if we were to measure jobless recoveries as deviations from the "natural rate," we would also find little trace of jobless recovery. Our evidence suggests that jobless recoveries mostly occur at lower frequencies than the ones typically studied in Okun's law regressions. At first sight, this result could be interpreted as a sign that financial crises are related to changes in the natural rate of unemployment (for a theoretical formulation and evidence related to this hypothesis, see Acemoglu, 2001; Dromel, Kolakez and Lehmann, 2009). However, our evidence that high-inflation recession episodes do not display jobless recovery suggests that this might be better characterized as persistent unemployment in the presence of low inflation and nominal rigidities - and therefore that a policy of generating a spike in inflation might succeed in reducing the unemployment rate.

To rationalize the findings of our empirical study, we develop a simple analytical framework in which financial crises - formalized as an exogenous contraction of collateral constraints - can lead to jobless recoveries. The key assumption is that collateral requirements are lower for projects and firms possessing easily recognizable collateral, such as physical capital. We thus show that, as a result of a collateral crunch, firms choose to employ more capital-intensive techniques, implying jobless recovery under wage rigidity. It is worth noting that, despite the simplicity of the model, collateral and other financial issues have not played a central role in the theoretical literature concerned with jobless recoveries (see Schreft, Singh and Hodgson, 2005; Shimer, 2012; Berger, 2012; Jaimovich 
and Siu, 2012; Schmitt-Grohé and Uribe, 2012). ${ }^{1}$ We then test the role of collateral for the sample of DMs, using data on asset prices (house prices) as a proxy for collateral values, and we find that, in a low-inflation context, the recovery of collateral variables is significantly associated with jobless recoveries.

The rest of the paper is organized as follows. Section 1 describes the sample of recession episodes and the variables used in the empirical analysis. Section 2 documents the association between financial crises and jobless and wageless recoveries and provides evidence from an instrumental variables strategy. Section 3 studies the results' robustness to the inclusion of additional controls and to the use of other measures of financial crises and jobless recovery. Section 4 presents an analytical framework to rationalize the association between financial crises and jobless recovery. Section 5 concludes.

\section{Data and Descriptive Statistics}

\subsection{Sample Construction}

\subsubsection{Developed- and Emerging-Market Recession Episodes}

To analyze the relationship between financial crises and labor-market recovery, we construct two samples of recession episodes: one for DMs and one for EMs. Constructing two separate samples allows us to use quarterly data in the DMs.

Using quarterly data, we construct a sample of recession episodes during the period 1950-2006 for 11 DMs: Austria, Australia, Canada, France, Germany, Italy, Spain, Sweden, Switzerland, the United Kingdom and the United States. We use the NBER (for the US) and the ECRI (for the other economies) recession dates to identify the occurrence of a recession event. ${ }^{2}$

For EMs, due to limited data availability, we use annual data and construct a sample of recession episodes from 1980 to 2006. Following Calvo, Izquierdo and Talvi (2006), we identify the occurrence of a recession event as a period of negative annual change in GDP. To reduce heterogeneity among EMs, we focus on countries that are integrated into the world capital market, defined as countries included in JP Morgan's Emerging Market Bond

\footnotetext{
${ }^{1}$ Financial considerations do play a key role in the dynamics of employment in both the theoretical and the empirical literature (for a recent survey see Brunnermeier, Eisenbach and Sannikov, 2012). However, the phenomenon of jobless recovery is different from that of employment fluctuations; it implies delinking employment from output.

${ }^{2}$ NBER and ECRI follow similar methodologies to define and date recessions. Countries were selected on the basis of data and recession dates' availability. Japan was not considered due to its strong idiosyncratic differences during this period. We did not include in the sample the 1995 episode in Austria, defined by the ECRI as recession, because there was no output contraction.
} 
Index (EMBI). Countries included in the sample are Argentina, Brazil, Bulgaria, Chile, Colombia, Croatia, the Czech Republic, the Dominican Republic, Ecuador, El Salvador, Hungary, Indonesia, Ivory Coast, Lebanon, Malaysia, Mexico, Morocco, Nigeria, Panama, Peru, the Philippines, Poland, Russia, South Africa, South Korea, Thailand, Tunisia, Turkey, Ukraine, Uruguay, and Venezuela. ${ }^{3}$

For each recession episode in a DM or EM, we define an output peak, trough, and recovery point using the cyclical component of output per capita. In particular, given a recession episode, we define an output peak as the period displaying the maximum cyclical component of output per capita in the window with a positive cyclical component of output per capita preceding the recession event. ${ }^{4}$ The recovery point is defined as the period, after a recession event, in which output per capita recovers its trend level. The output trough is defined as the period between output peak and recovery point displaying the minimum level of the cyclical component of output per capita. Since we are studying the pattern of the recovery from recession episodes, we do not include in the sample episodes in which output per capita did not fully recover its trend before the occurrence of another recession episode. We compute the cyclical component of output using a Hodrick-Prescott (HP) filter with a smoothing parameter of 1600 for quarterly data and 100 for annual data (Hodrick and Prescott, 1997; Ravn and Uhlig, 2002). Defining the recovery point of output per capita in terms of its trend level ensures that differences among episodes are not driven by different recoveries to trend. Results do not significantly change if we define the recovery point as the point in which output recovers its precrisis level rather than its trend. Data on output and population are obtained from OECD, WEO, and WDI datasets.

With this methodology, we obtain a sample of 45 DM recession episodes, and $71 \mathrm{EM}$ recession episodes, listed in Table 8 of Appendix A. Next we classify recession episodes according to the inflation rate exhibited during the recession episode.

\subsubsection{Low- and High-Inflation Recession Episodes}

A major difference between DMs and EMs is that recession episodes in the latter tend to display much higher inflation, as shown in Figure 3. In the presence of nominal wage

\footnotetext{
${ }^{3}$ Since we are interested in analyzing the recovery of unemployment in market economies during the crisis, we excluded from this sample episodes associated with the dissolution of the Soviet Union (in particular, the recession episodes that started prior to 1991 in Bulgaria, the Czech Republic, Croatia, Hungary, Poland, Russia and Ukraine).

${ }^{4}$ If no observation with a positive cyclical component of output exists between the trough of a previous recession episode and beginning of the recession event, the output peak is simply defined as the period displaying the maximum cyclical component of output per capita between the trough of the previous recession episode and the beginning of the recession event.
} 


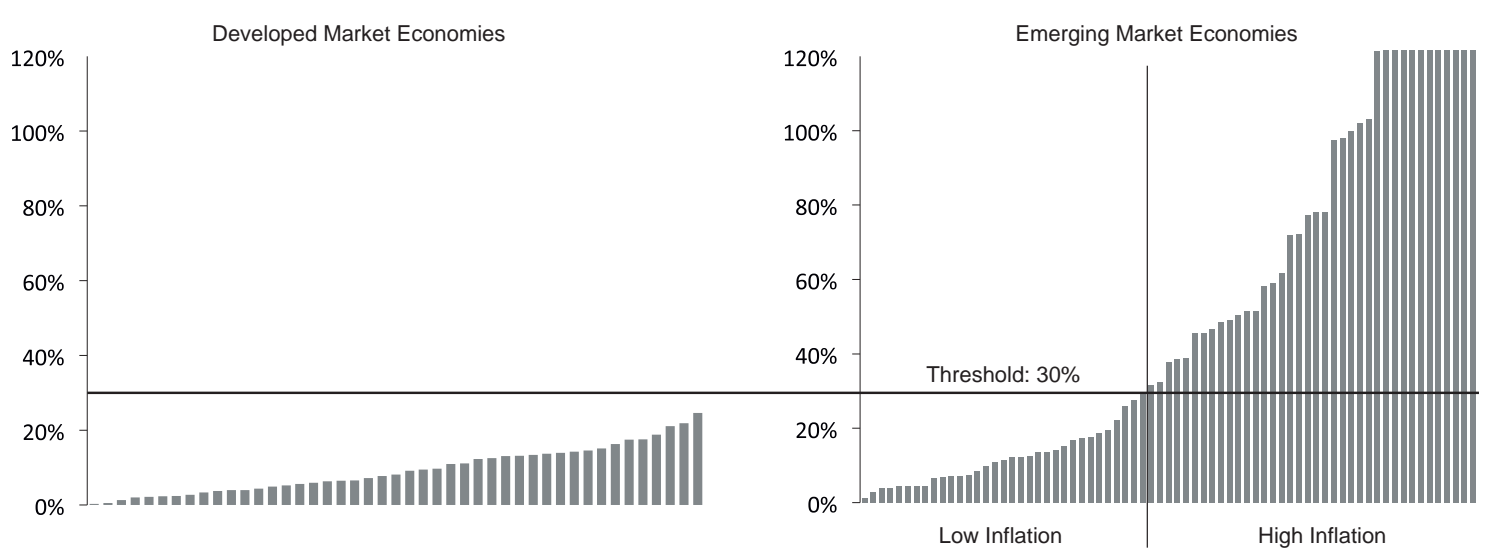

Figure 3: Inflation in Recession Episodes

Notes: Inflation refers to maximum level of annual inflation observed during the episode; See Section 1.1 for a description of the sample and data.

Data Source: IMF

rigidities, inflation is a potential mechanism to induce a contraction of real wages and thus restore full employment (see, for example, Galí, 2011; Schmitt-Grohé and Uribe, 2013). To explore this hypothesis, we divide the sample of EMs into "low inflation" episodes and "high inflation" episodes. For each episode, we compute the maximum level of inflation for the entire episode. We compute inflation using the producer price index (wholesale price index or the consumer price index when not available) obtained from the IMF dataset and national sources. The maximum annual level of inflation observed in a DM recession episode is 24.6 percent. We define a high- (low-) inflation episode as one in which the maximum level of the annual rate of inflation is above (below) 30 percent. ${ }^{5}$ The threshold considered is the upper bound identified in Dornbusch and Fischer (1993) to define moderate inflation, and the cutoff above which Calvo and Reinhart (2002) define high inflation. With this threshold, low-inflation EMs have an average inflation of 11.9 percent, not statistically different from the average DM inflation (9.4 percent). The standard deviation is also similar: 7.4 percent for low-inflation EMs and 6.2 percent for DMs. Thus, the distribution of low-inflation EMs is comparable, in terms of inflation during recession episodes, to that of DMs.

\footnotetext{
${ }^{5}$ In Calvo, Coricelli and Ottonello (2014), we conduct a threshold estimation, following Hansen (2000), to identify a level of inflation from which EM financial-crisis episodes have a different degree of jobless recovery. Results confirm the presence of a threshold around 30 percent (point estimate of 31.7 percent). We also study whether, in EM financial crises, one can establish a linear relationship between the inflation experienced in the episode (the level of inflation or the change in inflation) and unemployment recovery. We uncovered no strong evidence supporting the statistical significance of a linear relationship between a continuous measure of inflation and unemployment recovery.
} 


\subsection{Definition of Variables}

In this section we describe the data sources and the construction of the variables used in the empirical analysis.

\subsubsection{Measures of Jobless and Wageless Recovery}

To measure jobless recovery, we compute, for each episode, the change in the unemployment rate between output peak and output recovery point $\left(\Delta_{\mathrm{PR}} u\right)$. Looking at the change in the unemployment rate permits us to abstract from historical differences in the average unemployment rate in these economies, which is likely to be determined by structural characteristics and labor-market institutions. In the Section 3, we study the robustness of the results to alternative measures of jobless recovery. Similarly, to measure wageless recovery, we computed, for each episode, the change in the $(\log )$ real wage between output peak and output recovery point $\left(\Delta_{\mathrm{PR}} w\right)$. The data on unemployment and wages were obtained from WEO, ILO and ECLA datasets and from national sources. Nominal wages were deflated by the wholesale price index or producer price index, obtained from OECD and IFS datasets and national sources.

\subsubsection{Financial-Crisis Episodes}

For each recession episode, we construct a dummy variable (fin_crisis) that takes the value of one if a banking crisis event or a debt default/rescheduling event occurs in a window from 1 year before the output per capita peak to 1 year after the output per capita recovery point. This classifies 13 DM episodes as financial crises (29 percent of the sample) and 57 EM episodes ( 80 percent of the sample), detailed in Table 8 of Appendix A. Data on banking crises and debt default/rescheduling events are obtained from Reinhart and Rogoff (2009b).

\subsubsection{Control Variables}

The baseline empirical analysis includes two sets of controls (the set of controls is further expanded in Section 3). First, we control for labor-market indicators (denoted by labor_mkt $_{\mathrm{P}}$ ) computed at the output peak. As emphasized in the labor-market literature, labor-market institutions are likely to affect the response of unemployment to shocks, including the recovery of unemployment following recession episodes (see, for example, Bertola, Blau and Kahn, 2002; Blanchard, 2006; Furceri and Mourougane, 2009; BernalVerdugo, Furceri and Guillaume, 2012). We use two variables: a de jure indicator of 
labor-market legislation $\left(\right.$ lamrig $\left._{\mathrm{P}}\right)$ from the recent dataset on labor-market regulations constructed by Campos and Nugent $(2012) ;{ }^{6}$ and a de facto measure of labor-market rigidities, namely the natural rate of unemployment (natural_ $u_{\mathrm{P}}$ ), which is likely to be affected by labor-market institutions. For DMs, we use the natural rate of unemployment reported in the IMF-WEO dataset. For EMs we compute the average rate of unemployment in the whole sample period as a proxy for the natural rate of unemployment (to the best of our knowledge, there is no dataset available that reports the natural rate of unemployment for a large set of EM countries).

Second, we control for the secular growth experienced throughout the recession episode, denoted by $g d$. With $g$ denoting the annual secular growth rate of a given country and $d$ the duration of a recession episode, the secular growth experienced throughout the recession episode is defined as $g d=g \times d$. The secular growth rate for a given country is computed as the average per capita growth rate for the sample period. The duration of the recession episode is defined as the number of years from output peak to recovery point. Controlling for this variable is relevant since countries can have different long-run growth rates and recession episodes might differ in their duration, which can affect jobless and wageless recoveries. For instance, in a standard growth model, higher technological progress would lead to a higher growth of real wages.

\subsection{Descriptive Statistics}

Table 1 presents summary statistics for the sample of recession episodes, splitting the sample into DM and EM episodes and the latter into low- and high-inflation episodes. Columns 1-3 indicate that the average DM recession episode displays a statistically significant jobless recovery (from output peak to recovery, unemployment increases 2.2 percentage points) but no negative effect on wages (from output peak to recovery, wages increase 8.4 percent). If we split the DM sample between financial crises and other recession episodes, we see that financial crises display a greater increase in unemployment: 3.6 percent in financial crises vs. 1.6 percent in other recession episodes (see also Figure 2).

Columns 4-6 indicate that the average EM recession episode displays both statistically significant jobless and wageless recovery, driven by financial-crisis episodes (other recession episodes do not display a statistically significant jobless or wageless recovery). However, Columns 7-12 show that splitting the sample in low and high inflation uncovers two very

\footnotetext{
${ }^{6}$ The variable lamrig is an index of labor-market legislation rigidity, constructed in Campos and Nugent (2012) by reviewing labor-market legislation. This new index extends both in terms of country coverage and of time span the widely used OECD dataset on employment protection legislation (see also Botero et al., 2004).
} 
Table 1. Descriptive Statistics

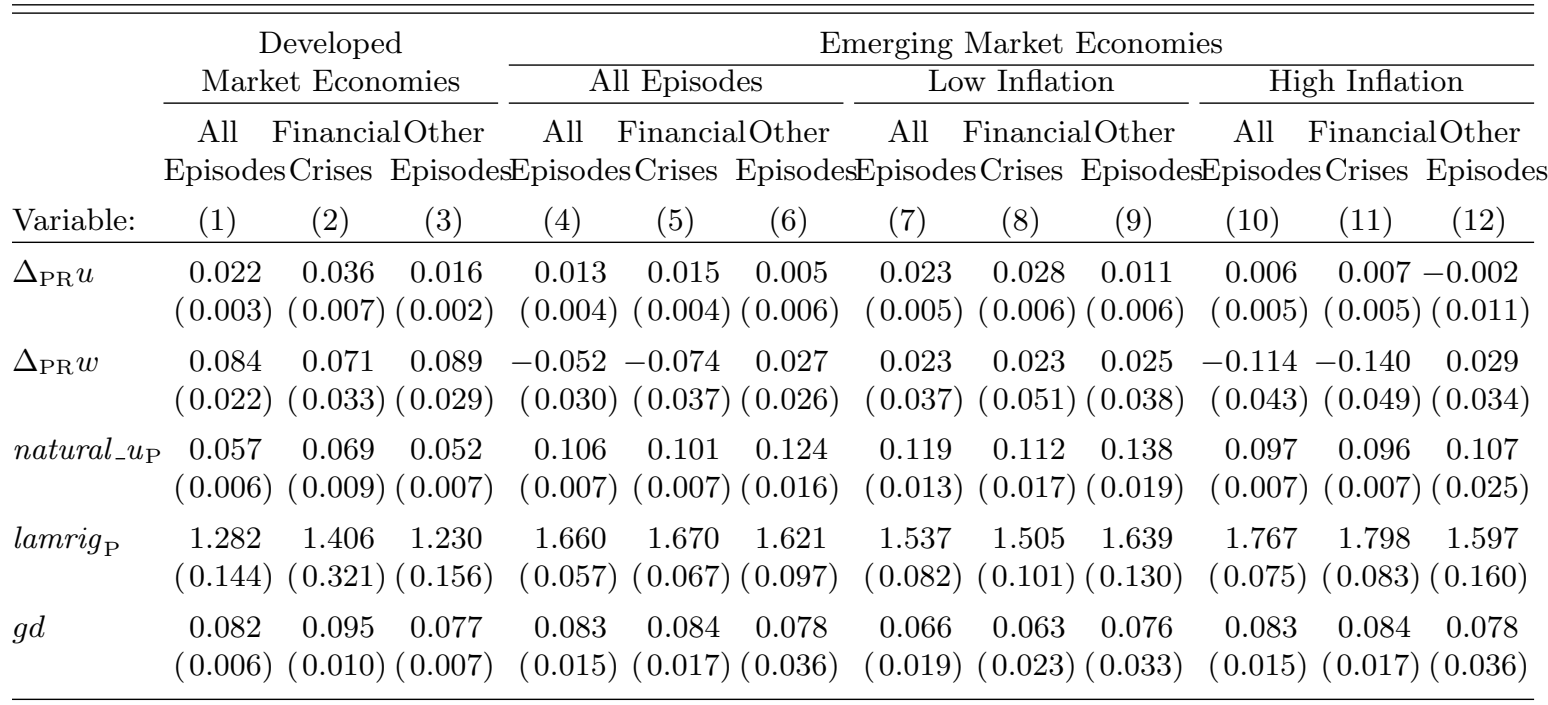

Notes: Standard errors in parentheses. Sample and variables definition are detailed in Section 1.

different patterns: low-inflation financial-crisis episodes display a statistically significant jobless recovery (from output peak to recovery, unemployment increases 2.8 percentage points) and no wageless recovery, while high-inflation financial-crisis episodes display no statistically significant jobless recovery and a large and statistically significant wageless recovery (from output peak to recovery, real wages contract 13 percent). As an illustration of this pattern see Figure 2.

Table 1 also shows the descriptive statistics of the baseline controls, which indicate that financial crises tend to occur more often in a context of higher labor-market rigidities, and to have a larger duration (which is reflected in the control variable $g d$ ). DM financial crises tend to occur more often in the context of a high natural rate of unemployment, whereas EM financial crises tend to occur in the context of a low natural rate of unemployment. These differences in the raw data point to the relevance of controlling for different characteristics of the recession episodes and of labor markets to identify the association between financial crises and labor-market recovery (Section 3 expands further this set of controls). 


\section{Econometric Analysis}

\subsection{Methodology}

The baseline empirical model relates jobless and wageless recoveries to financial crises, controlling for labor-market characteristics and secular growth:

$$
\Delta_{\mathrm{PR}} z_{i}=\alpha+\beta \text { fin_crisis }_{i}+X_{i}^{\prime}+\epsilon_{i} .
$$

where $\Delta_{\mathrm{PR}} z_{i}$ denotes the jobless recovery measure $\left(\Delta_{\mathrm{PR}} u_{i}\right)$ or wageless recovery measure $\left(\Delta_{\mathrm{PR}} w_{i}\right)$ in recession episode $i, \boldsymbol{X}$ is a vector of controls including labor-market controls $\left(\right.$ labor_mkt $\left._{\mathrm{P}, i}\right)$ and secular growth $\left(g d_{i}\right)$, and $\epsilon_{i}$ is a random error term (variables are defined in Section 1). The coefficient of interest is $\beta$, the difference in jobless recovery or wageless recovery displayed by financial-crisis episodes relative to other episodes.

The ordinary least squares (OLS) estimates of Equation (1) provide evidence for the association between financial crises and jobless recovery, but they cannot suggest any causality: Financial crises can be endogenous to jobless recoveries. For example, an increase in the unemployment rate driven by technological factors could induce a fall in house prices and a decrease in collateral values, triggering a financial crisis. We provide some evidence on the effect of financial crises on jobless and wageless recoveries using an IV strategy. The instrument is a variable that captures credit-market outcomes prior to the recession episode, as is typically done in the literature to predict financial crises (see, for example, Mendoza and Terrones, 2012; Schularick and Taylor, 2012; Gourinchas, Valdes and Landerretche, 2001). Specifically, we use the cyclical component of real per capita credit at the output peak $\left(\right.$ credit $\left._{\mathrm{P}}\right) .{ }^{7}$ Data on credit were obtained from the IFS dataset and from national sources.

Table 2 shows the first-stage relationship for DMs and EMs. The first-stage coefficients are statistically significant at the one- and 10-percent levels, showing that credit booms prior to recession episodes are associated with a higher probability of the recession being financial.

\subsection{Empirical Results}

Estimation results of Equation (1), linking financial crises to jobless and wageless recoveries, are reported in Table 3. Results for DMs are reported in Panel A. Columns 1-4

\footnotetext{
${ }^{7}$ The cyclical component of real per capita credit was obtained using an HP filter. Results do not change when we use a log quadratic trend to compute the cyclical component.
} 
TABle 2. First Stage: Credit Cycle at the Output Peak and Financial Crises

\begin{tabular}{|c|c|c|c|c|c|c|c|c|c|}
\hline \multirow[t]{4}{*}{ Dependent $\mathrm{V}$} & \multicolumn{9}{|c|}{ fin_crisis } \\
\hline & \multirow{2}{*}{\multicolumn{3}{|c|}{$\begin{array}{c}\text { Developed } \\
\text { Market Economies }\end{array}$}} & \multicolumn{6}{|c|}{ Emerging Market Economies } \\
\hline & & & & \multicolumn{3}{|c|}{ Low Inflation } & \multicolumn{3}{|c|}{ High Inflation } \\
\hline & $(1)$ & $(2)$ & $(3)$ & $(4)$ & $(5)$ & $(6)$ & $(7)$ & $(8)$ & $(9)$ \\
\hline credit $_{\mathrm{P}}$ & $\begin{array}{l}4.448^{* * *} \\
(1.515)\end{array}$ & $\begin{array}{l}4.900^{* * *} \\
(1.488)\end{array}$ & $\begin{array}{l}4.747^{* * *} \\
(1.514)\end{array}$ & $\begin{array}{r}0.737^{*} \\
(0.386)\end{array}$ & $\begin{array}{r}0.744^{*} \\
(0.419)\end{array}$ & $\begin{array}{r}0.768^{*} \\
(0.403)\end{array}$ & $\begin{array}{l}0.997^{* * *} \\
(0.235)\end{array}$ & $\begin{array}{l}{ }^{*} \begin{array}{l}0.970^{* * *} \\
(0.251)\end{array}\end{array}$ & $\begin{array}{l}1.008^{* * *} \\
(0.241)\end{array}$ \\
\hline natural_u $u_{\mathrm{P}}$ & & $\begin{array}{c}2.474 \\
(2.137)\end{array}$ & & & $\begin{array}{r}-0.386 \\
(1.887)\end{array}$ & & & $\begin{array}{c}0.108 \\
(0.602)\end{array}$ & $\begin{array}{c}0.448 \\
(0.618)\end{array}$ \\
\hline lamrig $_{\mathrm{P}}$ & & & $\begin{array}{l}-0.015 \\
(0.079)\end{array}$ & & & $\begin{array}{c}-0.023 \\
(0.170)\end{array}$ & & & $\begin{array}{c}0.242^{*} \\
(0.134)\end{array}$ \\
\hline$g d$ & & $\begin{array}{c}1.399 \\
(1.972)\end{array}$ & $\begin{array}{c}2.818 \\
(1.906)\end{array}$ & & $\begin{array}{c}0.470 \\
(1.133)\end{array}$ & $\begin{array}{c}0.619 \\
(0.885)\end{array}$ & & $\begin{array}{l}-1.476 \\
(1.554)\end{array}$ & \\
\hline Observations & 45 & 45 & 44 & 23 & 23 & 23 & 33 & 33 & 33 \\
\hline
\end{tabular}

Notes: Standard errors in parentheses. ${ }^{*}$ indicates significance at 10 percent level; ${ }^{* *}$ at 5 percent level; *** at 1 percent level. Sample and variables definition are detailed in Section 1.

show the association between jobless recoveries and financial crises. The OLS estimates, reported in Columns 1 and 2, indicate that there is a positive and statistically significant association between financial crises and jobless recoveries. Columns 3 and 4 show that the IV estimates are also positive and significant, providing evidence that the exogenous component of financial crises helps explain jobless recoveries. Note that the IV coefficients are larger than those of the OLS model, suggesting that the endogeneity of unemployment and financial crises could underestimate the effects. The magnitude of the coefficients suggests that jobless recoveries can be significantly larger during financial crises: When output per capita recovers its precrisis trend, the divergence from the unemployment rate at its precrisis level tends to be between 1.8 and 2.8 percentage points greater than in a regular recession. Note that these figures are similar to those observed in the United States and Europe during the global financial crisis that started in 2008 (see Figure 1). Columns 5-8 show the association between wageless recoveries and financial crises. None of the coefficients of the OLS or IV regressions is statistically significant. Therefore, in DMs, evidence suggests that financial crises are associated with jobless recoveries but not with the dynamics of real wages. In particular, there is no trace of wageless recoveries.

The results for low-inflation EMs are reported in Table 3, Panel B. As for DMs, evidence from OLS and IV estimates suggests that financial crises are associated with jobless recoveries (Columns 1-4) but not with wageless recoveries (Columns 5-8). The magnitude of the coefficient of jobless recoveries are similar to the one found for DMs.

The results for high-inflation EMs are reported in Table 3, Panel C. In sharp contrast with DMs and low-inflation EMs, financial crises in high-inflation EMs experience wageless rather than jobless recoveries. In Columns 1-4, both the OLS and IV estimates show that 
TABLE 3. Financial Crises and Labor Market Recovery

\begin{tabular}{|c|c|c|c|c|c|c|c|c|}
\hline \multirow{2}{*}{\multicolumn{2}{|c|}{$\begin{array}{r}\text { Dependent Variable: } \\
\text { OLS } \\
(1)\end{array}$}} & \multicolumn{2}{|c|}{$\Delta_{\mathrm{PR}} u$} & \multirow[b]{2}{*}{$\begin{array}{l}\text { IV } \\
(4)\end{array}$} & \multicolumn{4}{|c|}{$\Delta_{\mathrm{PR}} w$} \\
\hline & & $\begin{array}{c}\text { OLS } \\
(2) \\
\end{array}$ & $\begin{array}{l}\text { IV } \\
(3) \\
\end{array}$ & & $\begin{array}{c}\text { OLS } \\
(5) \\
\end{array}$ & $\begin{array}{c}\text { OLS } \\
(6) \\
\end{array}$ & $\begin{array}{l}\text { IV } \\
(7) \\
\end{array}$ & $\begin{array}{l}\text { IV } \\
(8)\end{array}$ \\
\hline \multicolumn{9}{|c|}{ Panel A: Developed Market Economies } \\
\hline fin_crisis & $\begin{array}{l}0.018^{* * *} \\
(0.005)\end{array}$ & $\begin{array}{c}0.019^{* * *} \\
(0.005)\end{array}$ & $\begin{array}{c}0.028^{* *} \\
(0.011)\end{array}$ & $\begin{array}{c}0.027^{* *} \\
(0.011)\end{array}$ & $\begin{array}{c}-0.032 \\
(0.052)\end{array}$ & $\begin{array}{c}-0.040 \\
(0.048)\end{array}$ & $\begin{array}{c}-0.141 \\
(0.164)\end{array}$ & $\begin{array}{c}-0.147 \\
(0.159)\end{array}$ \\
\hline natural_ $u_{\mathrm{P}}$ & $\begin{array}{c}-0.003 \\
(0.074)\end{array}$ & & $\begin{array}{c}-0.018 \\
(0.079)\end{array}$ & & $\begin{array}{c}-0.138 \\
(0.751)\end{array}$ & & $\begin{array}{c}0.173 \\
(0.913)\end{array}$ & \\
\hline lamrig $_{\mathrm{P}}$ & & $\begin{array}{c}0.003 \\
(0.003)\end{array}$ & & $\begin{array}{c}0.003 \\
(0.003)\end{array}$ & & $\begin{array}{c}-0.064^{* *} \\
(0.026)\end{array}$ & & $\begin{array}{c}-0.068^{* *} \\
(0.028)\end{array}$ \\
\hline$g d$ & $\begin{array}{c}0.136^{*} \\
(0.069)\end{array}$ & $\begin{array}{r}0.112^{*} \\
(0.065)\end{array}$ & $\begin{array}{c}0.121 \\
(0.074)\end{array}$ & $\begin{array}{c}0.092 \\
(0.071)\end{array}$ & $\begin{array}{c}0.857 \\
(0.684)\end{array}$ & $\begin{array}{l}1.602^{* *} \\
(0.603)\end{array}$ & $\begin{array}{c}0.925 \\
(0.736)\end{array}$ & $\begin{array}{l}1.873^{* *} \\
(0.755)\end{array}$ \\
\hline Observation & is 45 & 44 & 45 & 44 & 35 & 34 & 35 & 34 \\
\hline \multicolumn{9}{|c|}{ Panel B: Emerging Market Economies - Low Inflation } \\
\hline fin_crisis & $\begin{array}{c}0.020^{*} \\
(0.010)\end{array}$ & $\begin{array}{c}0.018^{*} \\
(0.010)\end{array}$ & $\begin{array}{c}0.076^{*} \\
(0.043)\end{array}$ & $\begin{array}{c}0.061^{*} \\
(0.035)\end{array}$ & $\begin{array}{c}0.039 \\
(0.107)\end{array}$ & $\begin{array}{c}-0.009 \\
(0.086)\end{array}$ & $\begin{array}{c}-0.401 \\
(0.422)\end{array}$ & $\begin{array}{c}-0.308 \\
(0.299)\end{array}$ \\
\hline natural_u $u_{\mathrm{P}}$ & $\begin{array}{c}0.121 \\
(0.084)\end{array}$ & & $\begin{array}{c}0.196 \\
(0.149)\end{array}$ & & $\begin{array}{c}1.221 \\
(0.986)\end{array}$ & & $\begin{array}{c}0.118 \\
(1.711)\end{array}$ & \\
\hline lamrig $_{\mathrm{P}}$ & & $\begin{array}{c}0.001 \\
(0.008)\end{array}$ & & $\begin{array}{c}0.002 \\
(0.011)\end{array}$ & & $\begin{array}{c}-0.019 \\
(0.082)\end{array}$ & & $\begin{array}{r}-0.039 \\
(0.102)\end{array}$ \\
\hline$g d$ & $\begin{array}{c}-0.019 \\
(0.050)\end{array}$ & $\begin{array}{c}-0.062 \\
(0.043)\end{array}$ & $\begin{array}{c}-0.016 \\
(0.083)\end{array}$ & $\begin{array}{c}-0.080 \\
(0.061)\end{array}$ & $\begin{array}{c}0.480 \\
(0.525)\end{array}$ & $\begin{array}{c}0.202 \\
(0.395)\end{array}$ & $\begin{array}{c}0.406 \\
(0.746)\end{array}$ & $\begin{array}{c}0.342 \\
(0.505)\end{array}$ \\
\hline Observation & hs $\quad 23$ & 23 & 23 & 23 & 21 & 27 & 21 & 27 \\
\hline \multicolumn{9}{|c|}{ Panel C: Emerging Market Economies - High Inflation } \\
\hline fin_crisis & $\begin{array}{c}0.011 \\
(0.014)\end{array}$ & $\begin{array}{c}0.011 \\
(0.014)\end{array}$ & $\begin{array}{c}0.024 \\
(0.025)\end{array}$ & $\begin{array}{c}0.024 \\
(0.023)\end{array}$ & $\begin{array}{c}-0.247^{* *} \\
(0.114)\end{array}$ & $\begin{array}{r}-0.236^{*} \\
(0.118)\end{array}$ & $\begin{array}{c}-0.397^{*} \\
(0.202)\end{array}$ & $\begin{array}{c}-0.359^{*} \\
(0.196)\end{array}$ \\
\hline natural_u $u_{\mathrm{P}}$ & $\begin{array}{c}0.043 \\
(0.126)\end{array}$ & & $\begin{array}{c}0.056 \\
(0.130)\end{array}$ & & $\begin{array}{c}-1.644 \\
(1.193)\end{array}$ & & $\begin{array}{c}-1.951 \\
(1.273)\end{array}$ & \\
\hline lamrig $_{\mathrm{P}}$ & $\begin{array}{c}-0.023 \\
(0.054)\end{array}$ & $\begin{array}{c}-0.022 \\
(0.058)\end{array}$ & $\begin{array}{c}-0.031 \\
(0.056)\end{array}$ & $\begin{array}{c}-0.034 \\
(0.061)\end{array}$ & $\begin{array}{l}1.113^{* *} \\
(0.444)\end{array}$ & $\begin{array}{l}1.181^{* *} \\
(0.498)\end{array}$ & $\begin{array}{l}1.232^{* *} \\
(0.475)\end{array}$ & $\begin{array}{l}1.317^{* *} \\
(0.535)\end{array}$ \\
\hline$g d$ & & $\begin{array}{c}0.000 \\
(0.012)\end{array}$ & & $\begin{array}{c}-0.002 \\
(0.013)\end{array}$ & & $\begin{array}{c}0.080 \\
(0.110)\end{array}$ & & $\begin{array}{c}0.107 \\
(0.118)\end{array}$ \\
\hline Observation & 35 & 35 & 35 & 35 & 33 & 33 & 33 & 33 \\
\hline
\end{tabular}

Notes: Standard errors in parentheses. * indicates significance at 10 percent level; ${ }^{* *}$ at 5 percent level; *** at 1 percent level. Sample and variables definition are detailed in Section 1.

financial crises have no statistically significant association with unemployment recovery. On the other hand, the association between financial crises and the recovery of real wages is negative and statistically significant, as shown by the OLS estimates in Columns 5 and 6. Moreover, Columns 7 and 8 show that the IV estimates are also statistically significant, providing some evidence that the exogenous component of financial crises can be important in wageless recoveries.

\section{Robustness}

In this section, we investigate the robustness of the results reported in Section 2. In particular, we explore the robustness of the conclusions when i) we use an alternative 
measure of financial crises, ii) we include additional controls, and iii) we use alternative measures of jobless recovery.

\subsection{Alternative Measure of Financial Crises}

The measure of financial crises used in the baseline specification is a dummy variable based on the occurrence of banking crises or default/rescheduling events during the recession window. In this section, we study the robustness of the findings to the use of a continuous measure of financial crises and credit-market conditions: the contraction in credit during the recession episode. In particular, the alternative measure of financial crises is defined as the change in the cyclical component of real credit per capita from output peak to recovery point $\left(\Delta_{\mathrm{PR}} \text { credit_c }_{-}\right)^{8}$

We estimate the model defined in Equation (1) with the alternative measure of financial crises:

$$
\Delta_{\mathrm{PR}} z_{i}=\alpha+\beta \Delta_{\mathrm{PR}} \text { credit_c } c_{i}+X_{i}^{\prime}+\epsilon_{i} .
$$

Table 4 indicates that the results using the alternative measure of financial crises are similar to those obtained in the baseline specification. In particular, Panel A shows that in DMs, creditless recoveries are associated with jobless recoveries and seem unrelated to the recovery of real wages. Panel B shows that the same pattern is observed in lowinflation EMs. Finally, Panel C reports that in high-inflation EMs creditless recoveries are associated with wageless recoveries and not jobless recoveries. In summary, focusing on continuous indicators of credit conditions, rather than dummy variables identifying financial crises, broadly confirms the results obtained in the financial-crisis analyses.

\subsection{Additional Controls}

In this section, we study the robustness of our results to the inclusion of additional controls that could be associated with jobless recoveries and financial crises. A first source of concern could be that the association between financial crises and labor-market recovery is driven by characteristics of financial crises relative to other recession episodes that are unrelated to financial factors. For instance, financial crises are typically associated with a larger output contraction than other recession episodes (see Reinhart and Rogoff,

\footnotetext{
${ }^{8}$ In the recession episodes in which a financial crisis occurs prior to or at the output peak, we consider the maximum level in the cyclical component of real per capita credit between the beginning of the financial crisis and the output peak instead of the cyclical component of real per capita credit at the output peak. Indeed, when a financial crisis starts before the recession episode, the level of credit at the output peak is already affected by the financial-crisis episode. The cyclical component of credit was computed using the HP filter, but results do not change if we use a log quadratic trend.
} 
TABle 4. Credit Recovery and Labor Market Recovery

\begin{tabular}{|c|c|c|c|c|c|c|c|c|}
\hline \multirow{2}{*}{\multicolumn{2}{|c|}{$\begin{array}{r}\text { Dependent Variable: } \\
\text { OLS } \\
(1) \\
\end{array}$}} & \multicolumn{3}{|c|}{$\Delta_{\mathrm{PR}} u$} & \multicolumn{4}{|c|}{$\Delta_{\mathrm{PR}} w$} \\
\hline & & $\begin{array}{l}\text { OLS } \\
(2) \\
\end{array}$ & $\begin{array}{l}\text { IV } \\
(3) \\
\end{array}$ & $\begin{array}{l}\text { IV } \\
(4) \\
\end{array}$ & $\begin{array}{l}\text { OLS } \\
(5)\end{array}$ & $\begin{array}{c}\text { OLS } \\
(6) \\
\end{array}$ & $\begin{array}{l}\text { IV } \\
(7)\end{array}$ & $\begin{array}{l}\text { IV } \\
(8) \\
\end{array}$ \\
\hline \multicolumn{9}{|c|}{ Panel A: Developed Market Economies } \\
\hline$\Delta_{\mathrm{PR}}$ credit & $\begin{array}{c}-0.104^{* *} \\
(0.040)\end{array}$ & $\begin{array}{c}-0.104^{* *} \\
(0.040)\end{array}$ & $\begin{array}{c}-0.109^{* *} \\
(0.045)\end{array}$ & $\begin{array}{c}-0.103^{* *} \\
(0.044)\end{array}$ & $\begin{array}{c}0.654 \\
(0.517)\end{array}$ & $\begin{array}{c}0.847^{*} \\
(0.474)\end{array}$ & $\begin{array}{c}0.600 \\
(0.640)\end{array}$ & $\begin{array}{c}0.606 \\
(0.586)\end{array}$ \\
\hline natural_u $u_{\mathrm{P}}$ & $\begin{array}{c}0.041 \\
(0.080)\end{array}$ & & $\begin{array}{c}0.042 \\
(0.080)\end{array}$ & & $\begin{array}{c}-0.230 \\
(0.721)\end{array}$ & & $\begin{array}{c}-0.230 \\
(0.722)\end{array}$ & \\
\hline lamrig $_{\mathrm{P}}$ & & $\begin{array}{c}0.003 \\
(0.003)\end{array}$ & & $\begin{array}{c}0.003 \\
(0.003)\end{array}$ & & $\begin{array}{c}-0.069^{* *} \\
(0.025)\end{array}$ & & $\begin{array}{c}-0.067^{* *} \\
(0.025)\end{array}$ \\
\hline$g d$ & $\begin{array}{l}0.152^{* *} \\
(0.074)\end{array}$ & $\begin{array}{c}0.146^{* *} \\
(0.070)\end{array}$ & $\begin{array}{c}0.151^{* *} \\
(0.074)\end{array}$ & $\begin{array}{l}0.147^{* *} \\
(0.070)\end{array}$ & $\begin{array}{c}0.862 \\
(0.670)\end{array}$ & $\begin{array}{l}1.616^{* * *} \\
(0.572)\end{array}$ & $\begin{array}{c}* 0.860 \\
(0.671)\end{array}$ & $\begin{array}{l}1.584^{* *} \\
(0.576)\end{array}$ \\
\hline Observations & is $\quad 45$ & 44 & 45 & 44 & 35 & 34 & 35 & 34 \\
\hline \multicolumn{9}{|c|}{ Panel B: Emerging Market Economies - Low Inflation } \\
\hline$\Delta_{\mathrm{PR}}$ credit & $\begin{array}{c}-0.034^{* *} \\
(0.014)\end{array}$ & $\begin{array}{c}-0.032^{* *} \\
(0.015)\end{array}$ & $\begin{array}{c}-0.048^{* * *} \\
(0.016)\end{array}$ & $\begin{array}{c}* 0.041^{* *} \\
(0.017)\end{array}$ & $\begin{array}{c}0.470 \\
(0.281)\end{array}$ & $\begin{array}{c}0.440^{*} \\
(0.233)\end{array}$ & $\begin{array}{c}0.472 \\
(0.326)\end{array}$ & $\begin{array}{c}0.367 \\
(0.269)\end{array}$ \\
\hline natural_ $u_{\mathrm{P}}$ & $\begin{array}{c}0.119 \\
(0.081)\end{array}$ & & $\begin{array}{c}0.129 \\
(0.083)\end{array}$ & & $\begin{array}{c}0.340 \\
(0.999)\end{array}$ & & $\begin{array}{c}0.337 \\
(1.037)\end{array}$ & \\
\hline lamrig $_{\mathrm{P}}$ & & $\begin{array}{c}0.001 \\
(0.008)\end{array}$ & & $\begin{array}{c}0.002 \\
(0.008)\end{array}$ & & $\begin{array}{c}0.014 \\
(0.078)\end{array}$ & & $\begin{array}{c}0.009 \\
(0.079)\end{array}$ \\
\hline$g d$ & $\begin{array}{c}-0.014 \\
(0.048)\end{array}$ & $\begin{array}{c}-0.057 \\
(0.041)\end{array}$ & $\begin{array}{c}-0.011 \\
(0.050)\end{array}$ & $\begin{array}{c}-0.058 \\
(0.041)\end{array}$ & $\begin{array}{c}0.313 \\
(0.497)\end{array}$ & $\begin{array}{c}0.348 \\
(0.374)\end{array}$ & $\begin{array}{c}0.312 \\
(0.501)\end{array}$ & $\begin{array}{c}0.323 \\
(0.378)\end{array}$ \\
\hline Observation: & is 23 & 23 & 23 & 23 & 21 & 27 & 21 & 27 \\
\hline \multicolumn{9}{|c|}{ Panel C: Emerging Market Economies - High Inflation } \\
\hline$\Delta_{\mathrm{PR}}$ credit & $\begin{array}{c}-0.002 \\
(0.016)\end{array}$ & $\begin{array}{c}-0.004 \\
(0.017)\end{array}$ & $\begin{array}{c}-0.020 \\
(0.021)\end{array}$ & $\begin{array}{c}-0.022 \\
(0.022)\end{array}$ & $\begin{array}{c}0.277^{*} \\
(0.147)\end{array}$ & $\begin{array}{c}0.290^{*} \\
(0.153)\end{array}$ & $\begin{array}{c}0.380^{*} \\
(0.193)\end{array}$ & $\begin{array}{c}0.367^{*} \\
(0.198)\end{array}$ \\
\hline natural_u $u_{\mathrm{P}}$ & $\begin{array}{c}0.028 \\
(0.134)\end{array}$ & & $\begin{array}{c}-0.019 \\
(0.140)\end{array}$ & & $\begin{array}{c}-1.009 \\
(1.192)\end{array}$ & & $\begin{array}{c}-0.962 \\
(1.204)\end{array}$ & \\
\hline lamrig $_{\mathrm{P}}$ & & $\begin{array}{c}0.003 \\
(0.013)\end{array}$ & & $\begin{array}{c}0.009 \\
(0.014)\end{array}$ & & $\begin{array}{c}-0.020 \\
(0.111)\end{array}$ & & $\begin{array}{c}-0.033 \\
(0.113)\end{array}$ \\
\hline$g d$ & $\begin{array}{c}-0.017 \\
(0.054)\end{array}$ & $\begin{array}{c}-0.012 \\
(0.058)\end{array}$ & $\begin{array}{c}-0.022 \\
(0.055)\end{array}$ & $\begin{array}{c}-0.008 \\
(0.059)\end{array}$ & $\begin{array}{l}1.038^{* *} \\
(0.447)\end{array}$ & $\begin{array}{r}0.969^{*} \\
(0.484)\end{array}$ & $\begin{array}{l}1.083^{* *} \\
(0.454)\end{array}$ & $\begin{array}{r}0.982^{*} \\
(0.487)\end{array}$ \\
\hline Observations & Is $\quad 35$ & 35 & 35 & 35 & 33 & 33 & 33 & 33 \\
\hline
\end{tabular}

Notes: Standard errors in parentheses. * indicates significance at 10 percent level; ** at 5 percent level; *** at 1 percent level. Sample and variables definition are detailed in Section 1. 
2009a). Jobless recoveries could result from deeper recession episodes if, for example, larger output contractions lead to greater increases in unemployment and there is hysteresis in unemployment. ${ }^{9}$ A second source of concern is that country characteristics, such as labormarket or financial-development indicators, are associated simultaneously with a higher frequency of financial crises and with jobless recoveries. The two sets of controls we have included in the baseline specification are aimed at addressing these concerns. In this section we study additional controls related to both episode-specific to country-specific characteristics. The following list describes each control:

- Depth of the recession episode $\left(\Delta_{\mathrm{PT}} y\right)$. Defined as the log change in GDP per capita from output peak to trough. Data source: WEO and WDI.

- Country's financial development (fin_development). Defined as the country's historical median (1980-2007) of the ratio of bank-provided domestic credit and GDP. Data source: WDI.

- Country size (small_country, medium_country and large_country). Defined as three dummy variables measuring the size of the population of a given country: small_country takes the value one when the country's population is below 20 million and zero otherwise; medium_country takes the value one when the country's population is between 20 and 80 million and zero otherwise; large_country takes the value one when the country's population is above 80 million and zero otherwise. Definition of thresholds and data source: Uribe and Schmitt-Grohé (2014).

- Country fixed effects. This analysis is only carried out for DMs. For EMs, the use of fixed effects is problematic as the number of countries in the sample is too large in relation to the overall sample, given by the number of recession episodes.

- Additional labor-market controls. For DMs, we can use an additional set of labormarket controls: those constructed by the OECD, which have been used in the empirical literature as determinants of unemployment rates across countries (see, for example, Scarpetta, 1996). In particular, we use unemployment benefits $(u b)$, the coverage of collective bargaining (colcov), and the degree of unionization of the labor force (union).

Table 5 reports the estimated coefficient associated with financial crises in Equation (1) including these additional controls. The results indicate that there is little change in

\footnotetext{
${ }^{9}$ Blanchard and Summer (1986) depicted the European experience as reflecting hysteresis in unemployment, a situation in which the natural rate of unemployment depends on the actual rate of unemployment. See also Ball (2009).
} 
this association between financial-crisis jobless and wageless recoveries after the inclusion of these variables.

\subsection{Alternative Measures of Jobless Recoveries}

The jobless-recovery measure used in the baseline specification is the change in the unemployment rate from output peak to recovery. This section studies the robustness of the results to two possible concerns related to this measure. A first concern might be that the measure is influenced by a low cyclical rate of unemployment at the output peak. To address this concern, we construct an alternative measure of jobless recovery, defined as the difference between the unemployment rate at the recovery point and the natural rate of unemployment at the output peak $\left(u_{\mathrm{R}}-\right.$ natural $\left._{-} u_{\mathrm{P}}\right)$. A second concern might be that the unemployment rate could also influenced by changes in the participation rate. To address this concern, we construct an alternative measure of jobless recovery defined as the change in the employment rate between output peak and recovery $\left(\Delta_{\mathrm{PR}} l\right)$.

We estimate Equation (1) with these two alternative measures of jobless recovery for DMs, in which we have more data coverage on the natural unemployment and employment rates. The results are presented in Table 6 and confirm the findings that emerged from the analysis with the change in unemployment rate as a jobless-recovery measure, suggesting that jobless recoveries are not driven by a low unemployment rate at the output peak or by changes in the participation rate.

It is worth noting that the measure of jobless recovery used in this paper differs from that used in other studies that define a jobless recovery as a deviation from the Okun's law, the difference between the unemployment rate and the natural unemployment rate (see, for example, Ball, Leigh and Loungani, 2013). To compare our findings with these studies, we decompose our jobless-recovery measure into two components: i) the deviation from Okun's law at the recovery point $\left(u_{\mathrm{R}}-\right.$ natural_ $\left.u_{\mathrm{R}}\right)$, and ii) the change in the natural unemployment rate between output peak and recovery point $\left(\Delta_{\mathrm{PR}}\right.$ natural_u$)$. We estimate Equation (1) for each of these measures. Results are presented in Table 6 and indicate that the major part of the effect found in this paper is driven by changes in the natural rate of unemployment. These changes would not be captured in studies that focus only on deviations from Okun's law. Nevertheless, our evidence that high-inflation recession episodes do not display jobless recoveries suggests that, more than an increase in the "natural rate," this pattern might be better characterized as persistent unemployment in the presence of low inflation and nominal rigidities. 
TABle 5. Financial Crises and Labor Market Recovery-Additional Controls

\begin{tabular}{|c|c|c|c|c|c|c|c|c|}
\hline \multicolumn{2}{|c|}{ Dependent Variable: } & \multicolumn{2}{|c|}{$\Delta_{\mathrm{PR}} u$} & \multirow[b]{2}{*}{$\begin{array}{l}\text { IV } \\
(4)\end{array}$} & \multicolumn{4}{|c|}{$\Delta_{\mathrm{PR}} w$} \\
\hline $\begin{array}{l}\text { Additional } \\
\text { Control: }\end{array}$ & $\begin{array}{c}\text { OLS } \\
(1)\end{array}$ & $\begin{array}{c}\text { OLS } \\
(2) \\
\end{array}$ & $\begin{array}{l}\text { IV } \\
(3) \\
\end{array}$ & & $\begin{array}{l}\text { OLS } \\
(5) \\
\end{array}$ & $\begin{array}{c}\text { OLS } \\
(6) \\
\end{array}$ & $\begin{array}{l}\text { IV } \\
(7) \\
\end{array}$ & $\begin{array}{l}\text { IV } \\
(8)\end{array}$ \\
\hline \multicolumn{9}{|c|}{ Panel A: Developed Market Economies } \\
\hline$\Delta_{\mathrm{PR}} y$ & $\begin{array}{l}0.018^{* * *} \\
(0.005)\end{array}$ & $\begin{array}{l}0.018^{* * *} \\
(0.005)\end{array}$ & $\begin{array}{c}0.025^{* *} \\
(0.011)\end{array}$ & $\begin{array}{c}0.023^{* *} \\
(0.011)\end{array}$ & $\begin{array}{c}-0.043 \\
(0.052)\end{array}$ & $\begin{array}{c}-0.041 \\
(0.048)\end{array}$ & $\begin{array}{c}-0.165 \\
(0.158)\end{array}$ & $\begin{array}{r}-0.168 \\
(0.164)\end{array}$ \\
\hline Observations & 45 & 44 & 45 & 44 & 35 & 34 & 35 & 34 \\
\hline fin_development & $\begin{array}{l}0.017^{* * *} \\
(0.005)\end{array}$ & $\begin{array}{l}0.018^{* * *} \\
(0.005)\end{array}$ & $\begin{array}{l}0.026^{* *} \\
(0.013)\end{array}$ & $\begin{array}{c}0.028^{* *} \\
(0.014)\end{array}$ & $\begin{array}{c}-0.041 \\
(0.053)\end{array}$ & $\begin{array}{c}-0.046 \\
(0.049)\end{array}$ & $\begin{array}{c}-0.126 \\
(0.159)\end{array}$ & $\begin{array}{r}-0.156 \\
(0.166)\end{array}$ \\
\hline Observations & 45 & 44 & 45 & 44 & 35 & 34 & 35 & 34 \\
\hline country_size & $\begin{array}{l}0.018^{* * *} \\
(0.005)\end{array}$ & $\begin{array}{l}0.019^{* * *} \\
(0.005)\end{array}$ & $\begin{array}{l}0.027^{* *} \\
(0.012)\end{array}$ & $\begin{array}{l}0.027^{* *} \\
(0.011)\end{array}$ & $\begin{array}{c}-0.042 \\
(0.054)\end{array}$ & $\begin{array}{c}-0.042 \\
(0.050)\end{array}$ & $\begin{array}{c}-0.138 \\
(0.153)\end{array}$ & $\begin{array}{c}-0.153 \\
(0.142)\end{array}$ \\
\hline Observations & 45 & 44 & 45 & 44 & 35 & 34 & 35 & 34 \\
\hline Country FE & $\begin{array}{l}0.016^{* * *} \\
(0.006)\end{array}$ & $\begin{array}{l}0.015^{* *} \\
(0.005)\end{array}$ & $\begin{array}{c}0.024 \\
(0.016)\end{array}$ & $\begin{array}{c}0.027^{*} \\
(0.015)\end{array}$ & $\begin{array}{c}-0.023 \\
(0.053)\end{array}$ & $\begin{array}{c}-0.019 \\
(0.054)\end{array}$ & $\begin{array}{c}-0.088 \\
(0.154)\end{array}$ & $\begin{array}{c}-0.098 \\
(0.134)\end{array}$ \\
\hline Observations & 45 & 44 & 45 & 44 & 35 & 34 & 35 & 34 \\
\hline$u b$ & $\begin{array}{l}0.018^{* * *} \\
(0.005)\end{array}$ & $\begin{array}{l}0.019^{* * *} \\
(0.005)\end{array}$ & $\begin{array}{l}0.027^{* *} \\
(0.012)\end{array}$ & $\begin{array}{l}0.027^{* *} \\
(0.012)\end{array}$ & $\begin{array}{c}-0.039 \\
(0.053)\end{array}$ & $\begin{array}{c}-0.036 \\
(0.048)\end{array}$ & $\begin{array}{c}-0.118 \\
(0.156)\end{array}$ & $\begin{array}{c}-0.137 \\
(0.161)\end{array}$ \\
\hline Observations & 42 & 41 & 42 & 41 & 35 & 34 & 35 & 34 \\
\hline colcov & $\begin{array}{l}0.019^{* * *} \\
(0.005)\end{array}$ & $\begin{array}{l}0.018^{* * *} \\
(0.005)\end{array}$ & $\begin{array}{c}0.027^{*} \\
(0.013)\end{array}$ & $\begin{array}{l}0.028^{* *} \\
(0.013)\end{array}$ & $\begin{array}{c}-0.042 \\
(0.053)\end{array}$ & $\begin{array}{c}-0.028 \\
(0.048)\end{array}$ & $\begin{array}{c}-0.115 \\
(0.149)\end{array}$ & $\begin{array}{l}-0.157 \\
(0.155)\end{array}$ \\
\hline Observations & 38 & 37 & 38 & 37 & 35 & 34 & 35 & 34 \\
\hline union & $\begin{array}{l}0.014^{* * *} \\
(0.005)\end{array}$ & $\begin{array}{l}0.015^{* * *} \\
(0.005)\end{array}$ & $\begin{array}{c}0.019 \\
(0.012)\end{array}$ & $\begin{array}{c}0.020 \\
(0.013)\end{array}$ & $\begin{array}{c}-0.026 \\
(0.053)\end{array}$ & $\begin{array}{c}-0.039 \\
(0.049)\end{array}$ & $\begin{array}{c}-0.063 \\
(0.163)\end{array}$ & $\begin{array}{c}-0.103 \\
(0.165)\end{array}$ \\
\hline Observations & 37 & 36 & 37 & 36 & 34 & 33 & 34 & 33 \\
\hline $\begin{array}{l}\text { Other Controls I } \\
{\text { natural_ } u_{\mathrm{P}}} \\
\text { lamrig }_{\mathrm{P}} \\
\text { gd }\end{array}$ & $\begin{array}{c}\text { Included } \\
\text { Y } \\
\mathrm{N} \\
\mathrm{Y}\end{array}$ & $\begin{array}{l}\mathrm{N} \\
\mathrm{Y} \\
\mathrm{Y}\end{array}$ & $\begin{array}{l}\mathrm{Y} \\
\mathrm{N} \\
\mathrm{Y}\end{array}$ & $\begin{array}{l}\mathrm{N} \\
\mathrm{Y} \\
\mathrm{Y}\end{array}$ & $\begin{array}{l}\mathrm{Y} \\
\mathrm{N} \\
\mathrm{Y}\end{array}$ & $\begin{array}{l}\mathrm{N} \\
\mathrm{Y} \\
\mathrm{Y}\end{array}$ & $\begin{array}{l}\mathrm{Y} \\
\mathrm{N} \\
\mathrm{Y}\end{array}$ & $\begin{array}{l}\mathrm{N} \\
\mathrm{Y} \\
\mathrm{Y}\end{array}$ \\
\hline \multicolumn{9}{|c|}{ Panel B: Emerging Market Economies - Low Inflation } \\
\hline$\Delta_{\mathrm{PR}} y$ & $\begin{array}{l}0.023^{* *} \\
(0.010)\end{array}$ & $\begin{array}{c}0.020^{*} \\
(0.010)\end{array}$ & $\begin{array}{c}0.070^{*} \\
(0.036)\end{array}$ & $\begin{array}{c}0.054^{*} \\
(0.030)\end{array}$ & $\begin{array}{c}-0.001 \\
(0.103)\end{array}$ & $\begin{array}{c}-0.037 \\
(0.079)\end{array}$ & $\begin{array}{c}-0.299 \\
(0.315)\end{array}$ & $\begin{array}{c}-0.193 \\
(0.217)\end{array}$ \\
\hline Observations & 23 & 23 & 23 & 23 & 21 & 27 & 21 & 27 \\
\hline fin_development & $\begin{array}{l}0.027^{* * *} \\
(0.009)\end{array}$ & $\begin{array}{l}0.022^{* *} \\
(0.010)\end{array}$ & $\begin{array}{l}0.061^{* *} \\
(0.026)\end{array}$ & $\begin{array}{r}0.045^{*} \\
(0.022)\end{array}$ & $\begin{array}{c}0.076 \\
(0.124)\end{array}$ & $\begin{array}{c}-0.014 \\
(0.090)\end{array}$ & $\begin{array}{c}-0.433 \\
(0.478)\end{array}$ & $\begin{array}{c}-0.307 \\
(0.301)\end{array}$ \\
\hline Observations & 23 & 23 & 23 & 23 & 21 & 27 & 21 & 27 \\
\hline country_size & $\begin{array}{l}0.021^{* *} \\
(0.010)\end{array}$ & $\begin{array}{c}0.016 \\
(0.011)\end{array}$ & $\begin{array}{c}0.021^{*} \\
(0.010)\end{array}$ & $\begin{array}{c}0.018 \\
(0.011)\end{array}$ & $\begin{array}{c}0.017 \\
(0.100)\end{array}$ & $\begin{array}{c}-0.007 \\
(0.087)\end{array}$ & $\begin{array}{c}-0.343 \\
(0.370)\end{array}$ & $\begin{array}{c}-0.206 \\
(0.365)\end{array}$ \\
\hline Observations & 23 & 23 & 23 & 23 & 21 & 27 & 21 & 27 \\
\hline \multicolumn{9}{|c|}{ Panel C: Emerging Market Economies - High Inflation } \\
\hline$\Delta_{\mathrm{PR}} y$ & $\begin{array}{c}0.011 \\
(0.015)\end{array}$ & $\begin{array}{c}0.011 \\
(0.015)\end{array}$ & $\begin{array}{c}0.026 \\
(0.027)\end{array}$ & $\begin{array}{c}0.026 \\
(0.026)\end{array}$ & $\begin{array}{c}-0.229^{*} \\
(0.119)\end{array}$ & $\begin{array}{c}-0.226^{*} \\
(0.130)\end{array}$ & $\begin{array}{c}-0.380 \\
(0.224)\end{array}$ & $\begin{array}{c}-0.375 \\
(0.237)\end{array}$ \\
\hline Observations & 35 & 35 & 35 & 35 & 33 & 33 & 33 & 33 \\
\hline fin_development & $\begin{array}{l}0.012 \\
(0.014)\end{array}$ & $\begin{array}{c}0.012 \\
(0.014)\end{array}$ & $\begin{array}{c}0.021 \\
(0.024)\end{array}$ & $\begin{array}{c}0.020 \\
(0.022)\end{array}$ & $\begin{array}{c}-0.251^{* *} \\
(0.115)\end{array}$ & $\begin{array}{c}-0.246^{* *} \\
(0.119)\end{array}$ & $\begin{array}{r}-0.369^{*} \\
(0.194)\end{array}$ & $\begin{array}{r}-0.327^{*} \\
(0.187)\end{array}$ \\
\hline Observations & 35 & 35 & 35 & 35 & 33 & 33 & 33 & 33 \\
\hline country_size & $\begin{array}{c}0.010 \\
(0.015)\end{array}$ & $\begin{array}{c}0.009 \\
(0.016)\end{array}$ & $\begin{array}{c}0.025 \\
(0.027)\end{array}$ & $\begin{array}{c}0.024 \\
(0.026)\end{array}$ & $\begin{array}{c}-0.288^{* *} \\
(0.117)\end{array}$ & $\begin{array}{c}-0.278^{* *} \\
(0.117)\end{array}$ & $\begin{array}{c}-0.377^{*} \\
(0.200)\end{array}$ & $\begin{array}{r}-0.371^{*} \\
(0.193)\end{array}$ \\
\hline Observations & 35 & 35 & 35 & 35 & 33 & 33 & 33 & 33 \\
\hline $\begin{array}{l}\text { Other Controls I } \\
\text { natural_ } u_{\mathrm{P}}\end{array}$ & $\begin{array}{c}\text { Included } \\
\text { Y }\end{array}$ & $\mathrm{N}$ & $\mathrm{Y}$ & $\mathrm{N}$ & $\mathrm{Y}$ & $\mathrm{N}$ & $\mathrm{Y}$ & $\mathrm{N}$ \\
\hline lamrig $_{\mathrm{P}}$ & $\mathrm{N}$ & $\mathrm{Y}$ & $\mathrm{N}$ & $\mathrm{Y}$ & $\mathrm{N}$ & $\mathrm{Y}$ & $\mathrm{N}$ & $\mathrm{Y}$ \\
\hline$g d$ & $\mathrm{Y}$ & $\mathrm{Y}$ & $\mathrm{Y}$ & $\mathrm{Y}$ & $\mathrm{Y}$ & $\mathrm{Y}$ & $\mathrm{Y}$ & $\mathrm{Y}$ \\
\hline
\end{tabular}

Notes: Each coefficient comes from a different regression. Standard errors in parentheses. $*^{\text {indicates }}$ significance at 10 percent level; ** at 5 percent level; *** at 1 percent level. Sample and variables definition are detailed in Section 1 and 3. 
TABle 6. Financial Crises and Alternative Measures of Jobless Recovery, Developed Market Economies

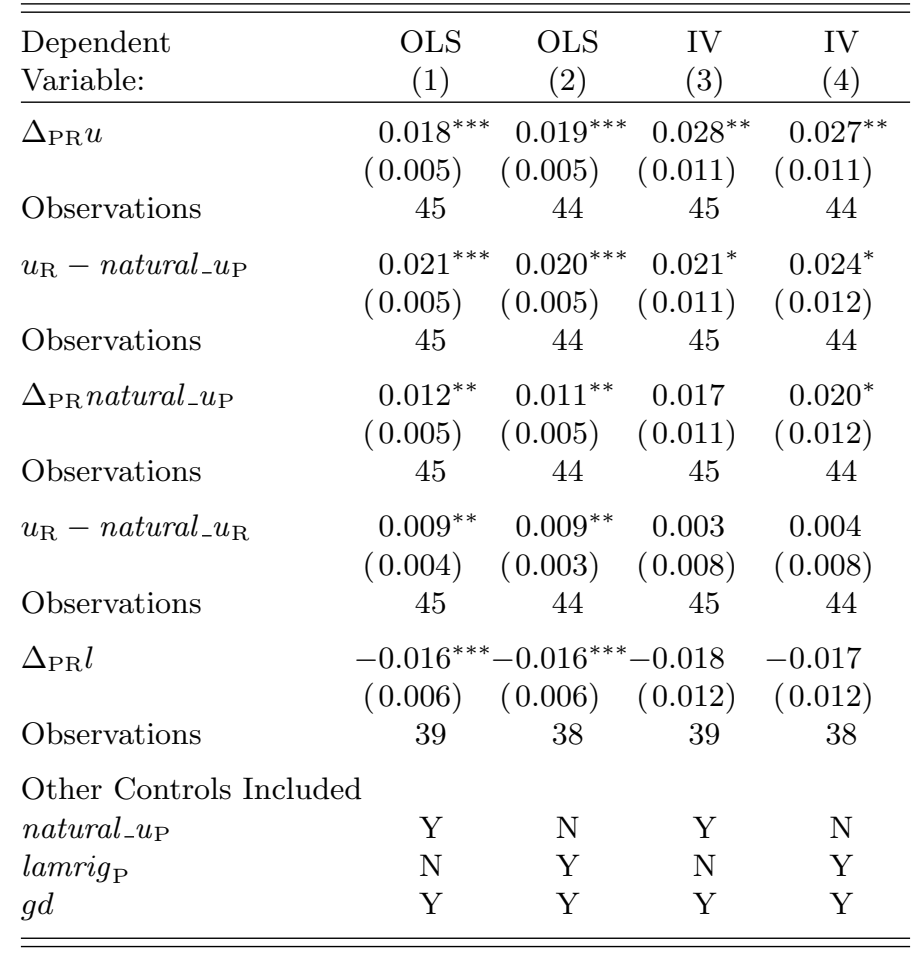

Notes: Each coefficient comes from a different regression. Standard errors in parentheses. $*^{\text {indicates }}$ significance at 10 percent level; ${ }^{* *}$ at 5 percent level; ${ }^{* * *}$ at 1 percent level. Sample and variables definition are detailed in Sections 1 and 3.

\section{Financial Crises and Jobless Recoveries: A Simple Ana- lytical Framework}

This section develops a simple analytical framework to help explain why financial crises are associated with jobless or wageless recoveries. This framework is based on two observations. The first observation, widely documented in the literature, is that financial crises typically impact collateral values (e.g., a fall in housing prices), tightening credit for firms. For our sample of recession episodes, this is documented in Figure 4. During financial-crisis episodes, real house prices contract 8.1 percent from output peak to trough and do not recover once output recover its trend. In other recession episodes, real house prices only contract 0.8 percent and recover their precrisis level together with output.

The second observation that motivates our analytical framework is that not all firms' projects require the same collateral per unit cost. Collateral requirements are lower for projects and firms possessing easily recognizable collateral (e.g., tangible assets) or "intrinsic collateral" (Calvo, 2011). As a large component of such intrinsic collateral is given by physical capital, tighter lending conditions might imply that credit is directed more towards projects that involve physical capital at the expense of projects involving job 

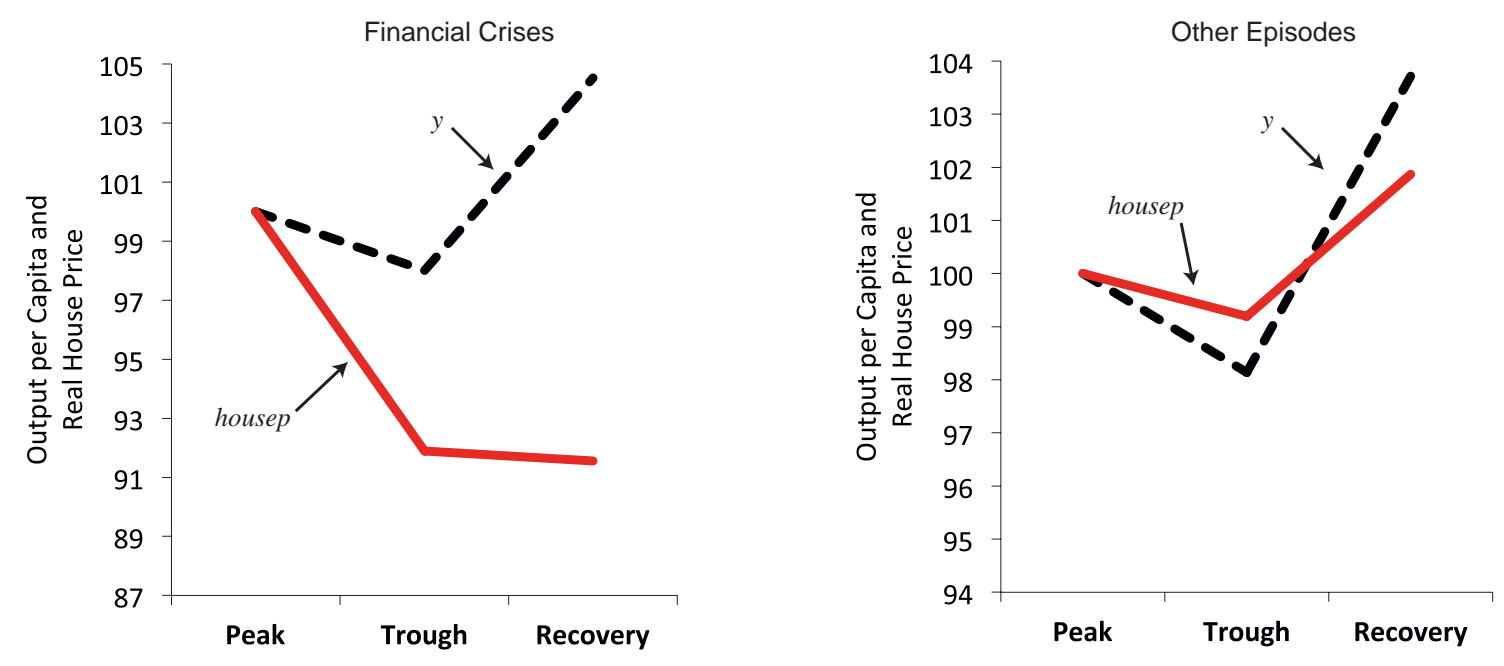

Figure 4: House Prices and Financial Crises: Developed Market Economies

Notes: See Section 1 for a description of the sample and data; $y$ refers to real GDP per capita, house $e_{\mathrm{P}}$ refers to real house prices, peak $=100$. Data on real house prices obtained from Cesa-Bianchi, Cespedes and Rebucci (2014).

creation, thus reducing the labor intensity of aggregate output.

In the rest of this section, we begin by formalizing this hypothesis and then provide some empirical evidence on the suggested channel. The model is based on a collateral channel, although it is conceivable that other specifications of the credit market could lead to similar conclusions.

\subsection{Analytical Framework}

Consider a firm that produces homogeneous output by means of capital $(K)$ and labor $(L)$. The production function is denoted by $A F(K, L)$, where $A$ stands for neutral technical progress, and function $F$ displays positive marginal productivities and strictly convex isoquants; $F$ is linear homogenous and twice continuously differentiable. Factors of production have to be hired a period in advance for which credit is required. Therefore, assuming that capital is fully depreciated at the end of the period, and the relevant rate of interest is zero (assumptions that can be relaxed without affecting the central results), profits are given by

$$
A F(K, L)-(K+W L)
$$

where $W$ stands for the wage rate plus search and other costs associated with labor hiring (measured in terms of output).

We assume that firms face a credit constraint,

$$
K+W L \leq Z+(1-\theta) K
$$


where $Z>0$ and $0 \leq \theta<1$. The left-hand side of Expression (4) corresponds to credit needs, while the right-hand side stands for total collateral. Total collateral consists of "extrinsic collateral," $Z$, defined as collateral provided by assets other than those involved in the project, and "intrinsic collateral," $(1-\theta) K$, defined as the collateral embodied in the project. This helps to capture a situation in which, under credit constraints, capital may be easier to finance than labor. If loans are not repaid, $(1-\theta) K$ can still be recovered by the creditors. In contrast, funds spent hiring labor cannot be recovered from the workers (unless somebody more skillful than Shylock is involved in the deal!). If $K$ is its own collateral, for example, $\theta=0$, then this constraint boils down to $w L \leq Z$ : labor would be the only input subject to a credit constraint, and capital could be accumulated in the standard manner.

This form of collateral constraint is related to the literature on the inalienability of human capital (Hart and Moore, 1994). In this framework, entrepreneurs cannot be costlessly replaced and can repudiate contracts by withdrawing their human capital. It is also related to the literature on asset tangibility. For example, Almeida and Campello (2007) show that pledgeable assets support more borrowing because such assets mitigate contractibility problems: Tangibility increases the value that can be captured by creditors in default states. Tangibility as a characteristic of assets used as collateral in debt contracts plays a central role in the corporate finance literature (Tirole, 2005).

The firm's problem is to choose $K$ and $L$ to maximize (3) subject to (4). Denoting with $\lambda$ the Lagrange multiplier associated with the credit constraint (4), the optimality conditions are given by (4), the first-order conditions,

$$
\begin{gathered}
A F_{K}(K, L)=1+\lambda \theta, \\
A F_{L}(K, L)=W(1+\lambda),
\end{gathered}
$$

and the complementary slackness conditions,

$$
\lambda \leq 0, \quad \lambda(Z-\theta K-W L)=0 .
$$

Conceivably, $Z$ is determined by the amount of collateral that the firm can credibly post, in addition to capital. A financial crisis can be modeled in this context as a contraction in $Z$ that triggers binding credit constraints. Proposition 1 shows that in this environment, under binding collateral constraints and for a given $Z$ and $W$, the profit-maximizing technology becomes more capital intensive as $A$ increases. 
Proposition 1. Around a solution of the firms' problem $\left(K^{*}, L^{*}\right)$ in which credit constraint (4) is strictly binding $(\lambda>0), \frac{\partial K^{*}}{\partial A}>\frac{\partial L^{*}}{\partial A}$.

Proof: See Appendix B.

This means that output and capital will grow faster than employment. Employment will lag behind output, which is the defining characteristic of a jobless recovery.

Figure 5 illustrates Proposition 1. As in Proposition 1, we focus on the case in which the credit constraint is strictly binding. The straight line in blue stands for the credit constraint (4), whose slope is given by $-\theta / W$. The convex curves are isoprofit lines. Under these conditions, recalling linear homogeneity, one can show that the isoprofit lines in the $(L, K)$ plane are strictly convex, and have the same slope along constant- $L / K$ rays from the origin. Solid and dashed lines correspond to two different families of isoprofit lines. An increase in the neutral technical progress parameter, $A$, implies that the isoprofit line becomes steeper, ${ }^{10}$ and thus an increase in $A$ is equivalent to a shift from the solid to the dashed isoprofit lines. Equilibrium under the solid lines holds at the blue tangent point, while that under the dashed lines holds at the red point. Therefore, under binding credit constraints, an increase in $A$ implies an increase in the capital-to-labor ratio.

Although a quantitative study including the mechanism suggested in this section is beyond the scope of this paper, Appendix C presents a numerical experiment using the analytical framework presented in this section and shows that the model can predict a jobless recovery in line with the one observed in the data for the US Great Recession.

\subsection{Some Empirical Evidence on the Collateral Channel}

To further study the transmission mechanism of the analytical framework presented in the previous section, we relate jobless recoveries to the contraction in collateral values, using data on real house prices as proxies for collateral values. These data on real house prices were obtained from Cesa-Bianchi, Cespedes and Rebucci (2014). We estimate an equation similar to (1):

$$
\Delta_{\mathrm{PR}} z_{i}=\alpha+\beta \Delta_{\mathrm{PT}} \text { house }_{-} p_{i}+X_{i}^{\prime} \gamma+\epsilon_{i} .
$$

\footnotetext{
${ }^{10} \mathrm{By}$ conditions (5) and (6), on a given isoprofit line $\frac{\partial L}{\partial K}=-\frac{A F_{K}(K, L)-1}{A F_{L}-W}<0$. This means that $\operatorname{sign} \frac{\partial \frac{\partial L}{\partial K}}{\partial A}=\operatorname{sign}\left[F_{L} \frac{\theta}{W}-F_{K}\right]$. Combining conditions (5) and (6), if $\theta<1, F_{L} \frac{\theta}{W}=\frac{1+\lambda}{\frac{1}{\theta}+\lambda} F_{K}<F_{K}$ and thus sign $\frac{\partial \frac{\partial L}{\partial K}}{\partial A}<0$, implying that the isoprofit lines in Figure 4 become steeper as $A$ increases.
} 


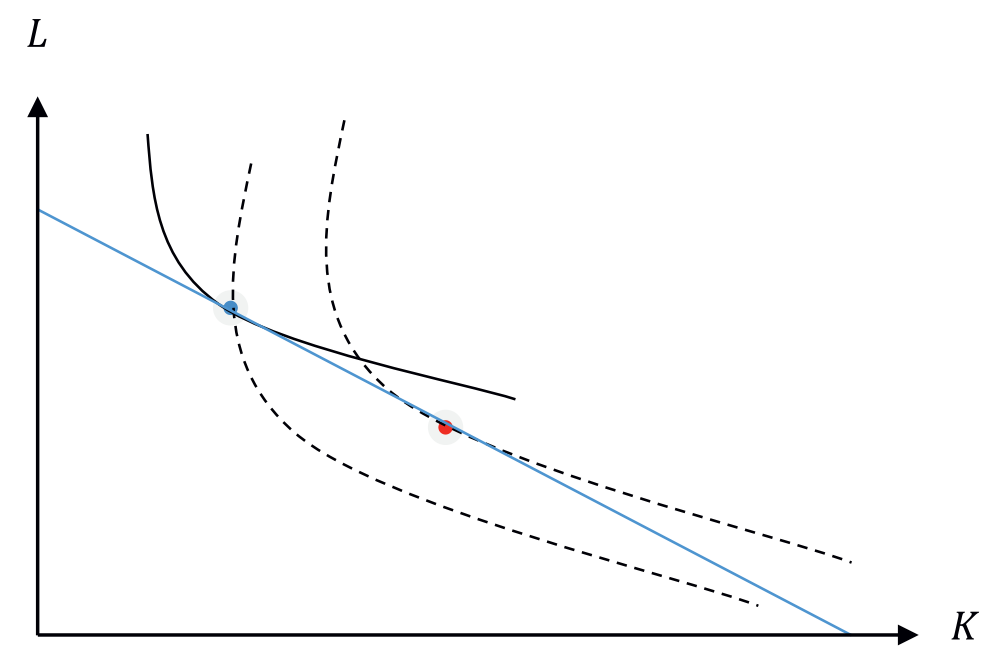

Figure 5: Optimal Input Vector under Credit Constraint

Notes: Blue line depicts the credit constraint (4), black curves are isoprofit lines. Solid and dashed lines correspond to two different families of isoprofit lines; an increase in $\mathrm{A}$ is equivalent to a shift from the solid to the dashed isoprofit lines.

where $\Delta_{\mathrm{PT}}$ house_p $p_{i}$ denotes the change in $(\log )$ real house prices from output peak to trough for recession epsiode $i$. Due to data availability, we provide evidence only for the DM sample. Table 7 presents results and suggests a negative relationship between the house-price contraction from output peak to trough and jobless recoveries. This result holds for all specifications, using baseline controls and additional controls (Section 3), such as country fixed effects. 
TABLE 7. Collateral Values and Jobless Recovery Developed Market Economies

\begin{tabular}{|c|c|c|c|c|c|c|c|c|c|c|c|c|c|c|c|c|}
\hline \multicolumn{7}{|c|}{ Dependent Variable: } & \multicolumn{10}{|c|}{$\Delta_{\mathrm{PR}} u$ (Estimation Method: OLS) } \\
\hline & $(1)$ & $(2)$ & $(3)$ & $(4)$ & $(5)$ & $(6)$ & $(7)$ & $(8)$ & $(9)$ & $(10)$ & $(11)$ & $(12)$ & $(13)$ & $(14)$ & $(15)$ & $(16)$ \\
\hline$\Delta_{\mathrm{PR}}$ house_p & $\begin{array}{c}-0.052^{* *} \\
(0.021)\end{array}$ & $\begin{array}{c}-0.054^{* *} \\
(0.021)\end{array}$ & $\begin{array}{c}-0.051^{* *} \\
(0.023)\end{array}$ & $\begin{array}{c}-0.049^{* *} \\
(0.023)\end{array}$ & $\begin{array}{c}-0.049^{* *} \\
(0.020)\end{array}$ & $\begin{array}{c}-0.053^{* *} \\
(0.020)\end{array}$ & $\begin{array}{c}-0.057^{* *} \\
(0.021)\end{array}$ & $\begin{array}{c}-0.063^{* * *} \\
(0.021)\end{array}$ & $\begin{array}{r}* 0.049^{* *} \\
(0.021)\end{array}$ & $\begin{array}{c}-0.052^{* *} \\
(0.021)\end{array}$ & $\begin{array}{c}-0.054^{* *} \\
(0.022)\end{array}$ & $\begin{array}{c}-0.052^{* *} \\
(0.021)\end{array}$ & $\begin{array}{c}-0.043^{* *} \\
(0.018)\end{array}$ & $\begin{array}{c}-0.043^{* *} \\
(0.019)\end{array}$ & $\begin{array}{c}-0.052^{* *} \\
(0.021)\end{array}$ & $\begin{array}{c}-0.054^{* * *} \\
(0.021)\end{array}$ \\
\hline natural_u $u_{\mathrm{P}}$ & $\begin{array}{c}0.023 \\
(0.093)\end{array}$ & & $\begin{array}{c}0.023 \\
(0.094)\end{array}$ & & $\begin{array}{c}-0.024 \\
(0.095)\end{array}$ & & $\begin{array}{c}-0.110 \\
(0.124)\end{array}$ & & $\begin{array}{c}0.027 \\
(0.093)\end{array}$ & & $\begin{array}{c}0.031 \\
(0.097)\end{array}$ & & $\begin{array}{c}0.096 \\
(0.083)\end{array}$ & & $\begin{array}{c}0.023 \\
(0.093)\end{array}$ & \\
\hline lamrig $_{\mathrm{P}}$ & & $\begin{array}{c}0.004 \\
(0.003)\end{array}$ & & $\begin{array}{c}0.005 \\
(0.004)\end{array}$ & & $\begin{array}{c}0.003 \\
(0.003)\end{array}$ & & $\begin{array}{c}0.005 \\
(0.003)\end{array}$ & & $\begin{array}{c}0.003 \\
(0.003)\end{array}$ & & $\begin{array}{c}0.006 \\
(0.005)\end{array}$ & & $\begin{array}{c}0.001 \\
(0.003)\end{array}$ & & $\begin{array}{c}0.004 \\
(0.003)\end{array}$ \\
\hline$g d$ & $\begin{array}{c}0.162^{*} \\
(0.084)\end{array}$ & $\begin{array}{r}0.147^{*} \\
(0.074)\end{array}$ & $\begin{array}{c}0.165^{*} \\
(0.090)\end{array}$ & $\begin{array}{l}0.156^{* *} \\
(0.076)\end{array}$ & $\begin{array}{l}0.172^{* *} \\
(0.082)\end{array}$ & $\begin{array}{c}0.132^{*} \\
(0.074)\end{array}$ & $\begin{array}{l}0.209^{* *} \\
(0.089)\end{array}$ & $\begin{array}{c}0.099 \\
(0.079)\end{array}$ & $\begin{array}{c}0.142 \\
(0.088)\end{array}$ & $\begin{array}{c}0.141^{*} \\
(0.076)\end{array}$ & $\begin{array}{c}0.146 \\
(0.088)\end{array}$ & $\begin{array}{c}0.122 \\
(0.080)\end{array}$ & $\begin{array}{c}0.016 \\
(0.079)\end{array}$ & $\begin{array}{c}0.071 \\
(0.073)\end{array}$ & $\begin{array}{r}0.162^{*} \\
(0.084)\end{array}$ & $\begin{array}{l}0.147^{* *} \\
(0.074)\end{array}$ \\
\hline$\Delta_{\mathrm{PR}} y$ & & & $\begin{array}{c}-0.009 \\
(0.089)\end{array}$ & $\begin{array}{c}-0.061 \\
(0.095)\end{array}$ & & & & & & & & & & & & \\
\hline fin_developm & nent & & & & $\begin{array}{c}0.000^{*} \\
(0.000)\end{array}$ & $\begin{array}{c}0.000 \\
(0.000)\end{array}$ & & & & & & & & & & \\
\hline small_countr & & & & & & & $\begin{array}{c}-0.010 \\
(0.009)\end{array}$ & $\begin{array}{c}-0.009 \\
(0.008)\end{array}$ & & & & & & & & \\
\hline medium_cou & untry & & & & & & $\begin{array}{c}0.005 \\
(0.007)\end{array}$ & $\begin{array}{c}0.001 \\
(0.007)\end{array}$ & & & & & & & & \\
\hline$u b$ & & & & & & & & & $\begin{array}{c}0.000 \\
(0.000)\end{array}$ & $\begin{array}{c}0.000 \\
(0.000)\end{array}$ & & & & & & \\
\hline colcov & & & & & & & & & & & $\begin{array}{c}0.000 \\
(0.000)\end{array}$ & $\begin{array}{c}0.000 \\
(0.000)\end{array}$ & & & & \\
\hline union & & & & & & & & & & & & & $\begin{array}{c}0.000 \\
(0.000)\end{array}$ & $\begin{array}{c}0.000 \\
(0.000)\end{array}$ & & \\
\hline Country FE & $\mathrm{N}$ & $\mathrm{N}$ & $\mathrm{N}$ & $\mathrm{N}$ & $\mathrm{N}$ & $\mathrm{N}$ & $\mathrm{N}$ & $\mathrm{N}$ & $\mathrm{N}$ & $\mathrm{N}$ & $\mathrm{N}$ & $\mathrm{N}$ & $\mathrm{N}$ & $\mathrm{N}$ & Y & Y \\
\hline Observations & 38 & 37 & 38 & 37 & 38 & 37 & 38 & 37 & 38 & 37 & 36 & 35 & 35 & 34 & 38 & 37 \\
\hline
\end{tabular}

Notes: Standard errors in parentheses. $*$ indicates significance at 10 percent level; $* *$ at 5 percent level; *** at 1 percent level. Sample and variables definition are detailed in Sections 1 and 4 


\section{Conclusions}

Financial crises are associated with bad labor-market outcomes. This is a central piece of evidence, which this paper shows for both DMs and EMs. An equally important piece of evidence is that the relationship between financial crises and labor-market outcomes depends on the inflation during the crisis episode. In low-inflation cases (all DMs cases and EMs cases that exhibit inflation below 30 percent annual rate during the recession episode), real wages appear to be downward inflexible, and the brunt of the adjustment comes in the form of high unemployment, measured at the point at which per-capita output recovers its trend. In contrast, under high inflation (EMs cases that exhibit inflation above 30 percent annual rate during the recession episode), unemployment goes back to precrisis levels at the output-recovery point, but real wages are significantly lower.

This suggests that labor-market outcomes during financial crises cannot easily be alleviated by standard expansionary monetary policy. For instance, the evidence suggests that a sharp rise in the price level can help to restore full employment, but at the expense of sharply lower real wages (close to -13 percent according to the average in high-inflation EMs; see Figure 2). This indicates that the use of monetary expansion to palliate high unemployment may encounter severe political opposition. Moreover, the EM experience is not helpful to assess the political feasibility in DMs because high inflation was an inevitable consequence of capital flight and resultant maxi-devaluations, not a calculated policy outcome. It is worth noting, incidentally, that there is no evidence in our sample that persistent inflation helps to lower unemployment (see Calvo, Coricelli and Ottonello, 2014). In the majority of high-inflation episodes, they occurred mostly within the crisis window and were followed by a return to previous inflation rates. Therefore, the evidence in no way contradicts the vertical Phillips curve conjecture.

Financial-crisis episodes are dramatic events that involve the central nervous system of capitalist economies. Hence, there are strong a priori intuitive considerations that make one expect those crises to be deeper and longer than most of the others. It is much less obvious why the labor market should suffer a significantly more powerful blow. To address this issue, the paper presents a simple model in which the financial shock takes the form of a drop in loan collateral values, and firms are assumed to be subject to a binding collateral constraint. This is a standard assumption in the macroeconomic literature (see, for example, Brunnermeier, Eisenbach and Sannikov, 2012). The relatively new twist in the model is that it assumes that labor costs are harder to collateralize than physical capital because, as a general rule, a share of physical capital can be attached by the 
creditor in case of default, while hiring costs, for example, are more like "autumn leaves," hard to grab and harder to price. This slants credit in favor of capital-intensive projects and exacerbates a jobless or wageless recovery. Preliminary tests of this conjecture are encouraging.

The additional evidence about the role of loan collateral further supports the view that standard fiscal and monetary policies may be ineffective in speeding full recovery and suggests that studying policies that address the weaknesses of the credit market should take center stage. Examples include debt restructuring and labor subsidies. Searching for policies of this kind that are both effective and politically viable should be at the top of the policy research agenda to provide guidance to policy intervention during financial crises

\section{References}

Acemoglu, D. 2001. "Credit Market Imperfections and Persistent Unemployment." European Economic Review, 45(4-6): 665-679.

Almeida, H., and M. Campello. 2007. "Financial Constraints, Asset Tangibility, and Corporate Investment." Review of Financial Studies, 20: 1429-1460.

Ball, L. 2009. "Hysteresis in Unemployment: Old and New Evidence." NBER. Working paper 14818 .

Ball, L. M., D. Leigh, and P. Loungani. 2013. "Okun's Law: Fit at Fifty?" NBER. Working paper 18668.

Berger, D. 2012. "Countercyclical Restructuring and Jobless Recoveries,." Yale University. Mimeograph.

Bernal-Verdugo, L., D. Furceri, and D. Guillaume. 2012. "Crises, Labor Market Policy, and Unemployment,." IMF. Working paper No. 12/65.

Bertola, G., F. Blau, and L. Kahn. 2002. "Labour Market Institutions and Demographic Employment Patterns,." NBER. Working paper 9043.

Blanchard, O. 2006. "European Unemployment: The Evolution of Facts and Ideas." Economic Policy, 21(45): 5-59.

Blanchard, O., and L. Summer. 1986. "Hysteresis and the European Unemployment Problem." In NBER Macroeconomics Annual 1986. Vol. 1, 15-90. MIT Press. 
Botero, J., S. Djankov, R. La Porta, F. Lopez de Silanes, and A. Shleifer. 2004.

"The Regulation of Labor." Quarterly Journal of Economics, 119: 1339-1382.

Brunnermeier, M., T. Eisenbach, and Y. Sannikov. 2012. "Macroeconomics with Financial Frictions: A Survey." Vol. 2, 3-94, Tenth World Congress of the Econometric Society. Cambridge University Press.

Calvo, G. 2011. "The Liquidity Approach to Bubbles, Crises, Jobless Recoveries, and Involuntary Unemployment,." Columbia University. Mimeograph.

Calvo, G., A. Izquierdo, and E. Talvi. 2006. "Phoenix Miracles in Emerging Markets: Recovering without Credit from Systemic Financial Crisis,." NBER. Working paper 1201.

Calvo, G., and C. M. Reinhart. 2002. "Fear of Floating." The Quarterly Journal of Economics, 117(2): 379-408.

Calvo, G., F. Coricelli, and P. Ottonello. 2014. "Jobless Recoveries during Financial Crises: Is Inflation the Way Out?" In Macroeconomic and Financial Stability: Challenges for Monetary Policy. , ed. S. Bauducco, L. Christiano and C. Raddatz, forthcoming. Central Bank of Chile.

Campos, N., and J. Nugent. 2012. "The Dynamics of the Regulation of Labor in Developing and Developed Countries since 1960." University of Southern California. Mimeograph.

Cesa-Bianchi, A. L.F. Cespedes, and A. Rebucci. 2014. "Capital Flows, House Prices, and the Macroeconomy: Evidence from Advanced and Emerging Market Economies." Federal Reserve Bank of Dallas. Mimeograph.

Dornbusch, R., and S. Fischer. 1993. "Moderate Inflation." The World Bank Economic Review, 7(1): 1-44.

Dromel, N., E. Kolakez, and E. Lehmann. 2009. "Credit Constraints and Unemployment Persistence." IZA. Discussion paper no. 4501.

Fernald, J. 2012. "A quarterly, utilization-adjusted series on total factor productivity,." Federal Reserve Bank of San Francisco. Mimeograph.

Furceri, D., and A. Mourougane. 2009. "The Effects of Financial Crises on Potential Output: New Empirical Evidence from OECD Countries,." OECD Economic Department. Working paper No. 669. 
Galí, J. 2011. Unemployment Fluctuations and Stabilization Policies: A New Keynesian Perspective. MIT Press.

Galí, J., F. Smets, and R. Wouters. 2012. "Slow Recoveries: A Structural Interpretation." Journal of Money, Credit and Banking, 44: 9-30.

Gourinchas, P. O., R. Valdes, and O. Landerretche. 2001. "Lending Booms: Latin America and the World." Journal of LACEA Economia, 1(2): Article 3.

Hansen, B. E. 2000. "Sample Splitting and Threshold Estimation." Econometrica, 68(3): 575-603.

Hart, O., and J. Moore. 1994. "A Theory of Debt Based on the Inalienability of Human Capital." Quarterly Journal of Economics, 109(4): 841-879.

Hodrick, R. J., and E. C. Prescott. 1997. "Postwar U.S. Business Cycles: An Empirical Investigation." Journal of Money, Credit and Banking, 29: 1-16.

Jaimovich, N., and H. E. Siu. 2012. "The Trend Is the Cycle: Job Polarization and Jobless Recoveries,." NBER. Working paper 18334.

Knotek, E. S., and S. Terry. 2009. "How Will Unemployment Fare Following the Recession?" Economic Review, 2009(3): 5-33.

Mendoza, E. G., and M. E. Terrones. 2012. "An Anatomy of Credit Booms and Their Demise,." NBER. Working paper 18379.

Ravn, M., and H. Uhlig. 2002. "On Adjusting the Hodrick-Prescott Filter for the Frequency of Observations." Review of Economics and Statistics, 84(2): 371-376.

Reinhart, C., and K. Rogoff. 2009a. "The Aftermath of Financial Crises." American Economic Review, 99(2): 466-472.

Reinhart, C., and K. Rogoff. 2009b. This Time is Different: Eight Centuries of Financial Folly. Princeton University Press.

Reinhart, C., and V. Reinhart. 2010. "After the Fall,." NBER. Working paper 16334.

Scarpetta, S. 1996. "Assessing the Role of Labour Market Policies and Institutional Settings on Unemployment: A Cross Country Study." OECD Economic Studies, 1996(26): 43-97. 
Schmitt-Grohé, S., and M. Uribe. 2012. "The Making of a Great Contraction with a Liquidity Trap and a Jobless Recovery,." Columbia University. Mimeograph.

Schmitt-Grohé, S., and M. Uribe. 2013. "Downward Nominal Wage Rigidity, Currency Pegs, and Involuntary Unemployment,." Columbia University. Mimeograph.

Schreft, S. L., A. Singh, and A. Hodgson. 2005. "Jobless Recoveries and the Waitand-See Hypothesis." Economic Review, 90(4): 81.

Schularick, M., and A. Taylor. 2012. "Credit Booms Gone Bust: Monetary Policy, Leverage Cycles and Financial Crises, 1870-2008." American Economic Review, 102(2): 1029-1061.

Shimer, R. 2012. "Wage Rigidities and Jobless Recoveries." Journal of Monetary Economics, 59: S65-S77.

Tirole, J. 2005. The Theory of Corporate Finance. Princeton University Press.

Uribe, M., and S. Schmitt-Grohé. 2014. Open Economy Macroeconomics. Columbia University. 


\section{A List of Recession Episodes}

Table 8 lists the recession episodes included in the empirical analysis. The identification of recession episodes and their classification into low and high inflation and financial crises and other episodes is detailed in Section 1.

TABLE 8. Sample Recession Episodes

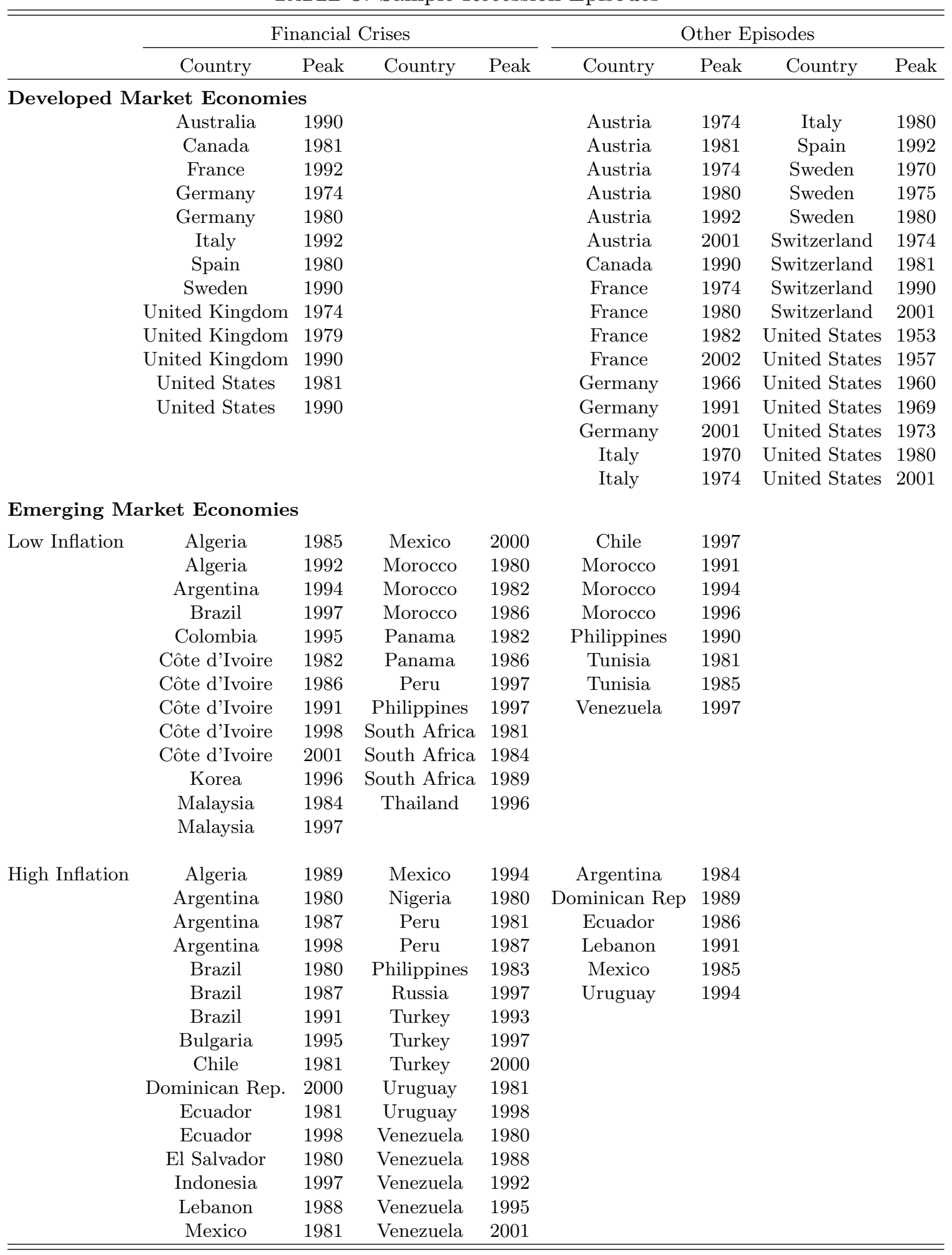




\section{B Proof of Proposition 1}

Around a solution of the firms' problem $\left(K^{*}, L^{*}\right)$ in which $\lambda>0$, the complementary slackness condition (7) implies that (4) holds with equality: $(Z-\theta K-W L)=0$. First, consider the case with $\theta>0$. This means that $L=(Z / W-(\theta / W) K) \equiv L(K)$, with $\partial L(K) / \partial K<0$. Combining conditions (5) and (6), we obtain

$$
S(K, A) \equiv A\left(F_{L}(K, L(K))-\frac{W}{\theta} F_{K}(K, L(K))\right)+W\left(\frac{1}{\theta}-1\right)=0 .
$$

By the implicit function theorem,

$$
\frac{\partial K}{\partial A}=\frac{\partial S(K, A) / \partial K}{\partial S(K, A) / \partial A}
$$

If $\theta<1, \partial K / \partial A>0$ since

$$
\frac{\partial S(K, A)}{\partial A}=\left(F_{L}(K, L(K))-\frac{W}{\theta} F_{K}(K, L(K))\right)=\frac{W}{A}\left(1-\frac{1}{\theta}\right)<0
$$

and, by linear homogeneity and diminishing return on each factor,

$$
F_{L K}+F_{L L} \frac{\partial L(K)}{\partial K}-\frac{W}{\theta} F_{K K}+-\frac{W}{\theta} F_{K L} \frac{\partial L(K)}{\partial K}>0
$$

Finally (4) holding with equality implies that $\partial L / \partial A<0$ and thus $\partial L / \partial A<\partial K / \partial A$. Second, consider the case with $\theta=0$. Equation (4) holding with equality implies that $L=Z / W$ and thus $\partial L / \partial A=0$. Equation (5) implies that $A F_{K}(K, Z / W)=1$, and the implicit function theorem implies that $\partial K / \partial A>0$ and thus $\partial L / \partial A<\partial K / \partial A$.

\section{A Quantitative Exercise of the Analytical Framework}

In this section, we perform a simple quantitative exercise to show that the analytical framework presented in Section 4 can rationalize actual jobless recovery episodes. In particular, we calibrate the model and compare its predictions with actual data from the US Great Recession. We begin by assuming the technology is Cobb-Douglas:

$$
F(K, L)=K^{\alpha} L^{1-\alpha}
$$

We assume, for simplicity, that $\theta=0$, corresponding to the case in which $K$ is its own collateral. Furthermore, we assume that real wages are constant $\left(\Delta w_{t}=0\right.$ for every $\left.t\right)$. 
This assumption is consistent with US data for the Great Recession (Shimer, 2012). We now solve the model for the case in which the credit constraint is binding, and thus Equation (4) holds with equality. Thus, $w L=Z$ and profits can be expressed as

$$
A Z^{1-\alpha}=K^{\alpha}-(K+Z)
$$

The first-order condition with respect to capital implies

$$
K=\alpha^{\frac{1}{1-\alpha}} Z A^{\frac{1}{1-\alpha}}
$$

Hence, assuming discrete time and denoting for any variable $X, \Delta x_{t}=\log X_{t}-\log X_{t-1}$, we get

$$
\begin{gathered}
\Delta l_{t}=\Delta z_{t} \\
\Delta k_{t}=\frac{1}{1-\alpha} \Delta a_{t}+\Delta z_{t} .
\end{gathered}
$$

Our aim is to compare the model's prediction for $L$ and $K$ with US data during the Great Recession. The time unit is set equal to a quarter. We obtain data for $L, K, A$ and utilization from Fernald (2012). For $L$, we use hours worked; for $A$, we use total factor productivity adjusted by utilization. We estimate $Z$, as the process consistent with the model that reproduces the actual behavior of $Y$, that is, using (12) and (13), $\Delta z_{t}=\Delta y_{t}-1 /(1-\alpha) \Delta a_{t}$. Following the estimate of Fernald (2012) for 2007, we set $\alpha=0.35$ the year prior to the crisis. Results are presented in Figure 6. Panels a) and b) show the behavior of $A$ and $Z$, the model's inputs. It can be seen that $A$ increases throughout the episode, while the estimated $Z$ displays a sharp contraction, consistent with the behavior of output. Panels c) and d) depict the behavior of $L$ and $K$. It can be observed that employment behavior predicted by the model tracks closely the actual path of employment. In particular, the model predicts a jobless recovery similar to the one observed in the data. 
a) Total Factor Productivity

(Adjusted by utilization, Dec-2007 = 100)

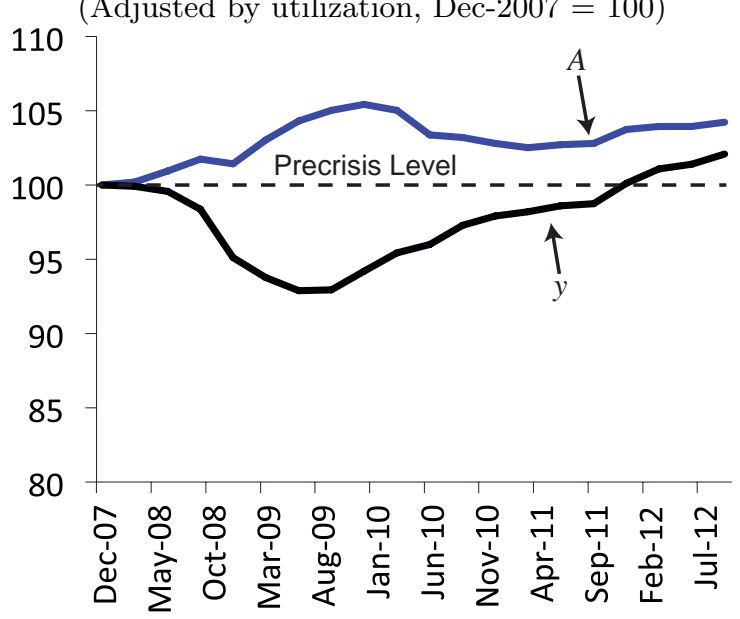

c) Labor

(Hours worked, Dec-2007 = 100)

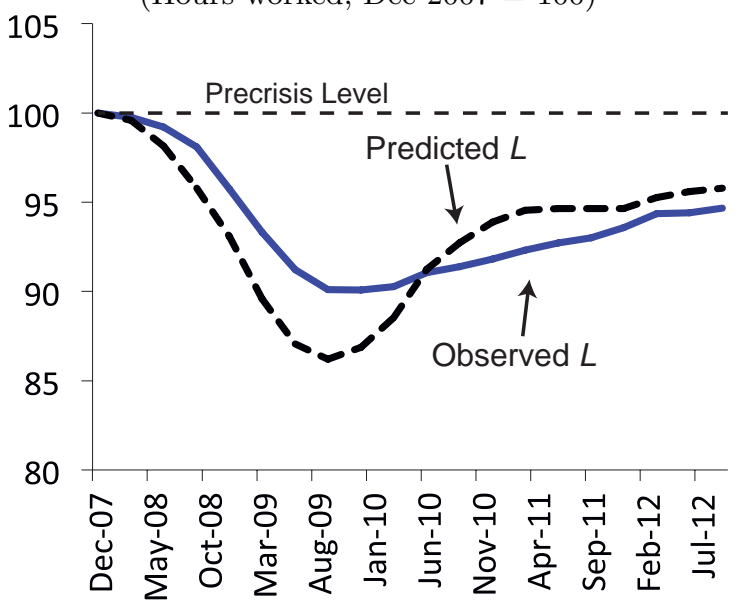

b) "Extrinsic" Collateral

(Estimated to match output, Dec-2007 = 100)

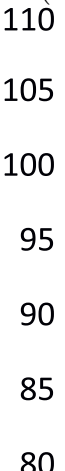

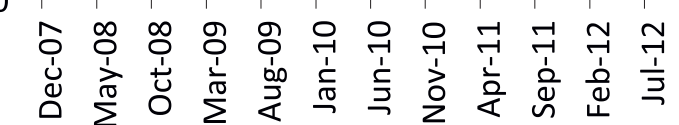

d) Capital and Utilization

$($ Dec-2007 $=100)$

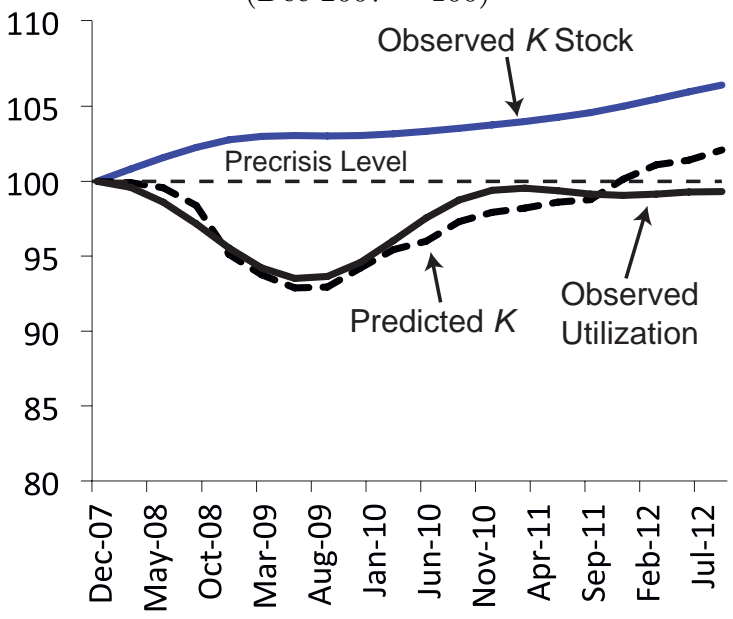

Figure 6: Model Predictions: US Great Recession

Data Source: TFP adjusted by utilization, observed labor, capital and utilization: Fernald (2012) 